\title{
Tectonic evolution of the Juruena magmatic arc between the Aripuanã and Juruena rivers: northwest Mato Grosso State, Brazil
}

\author{
Tiago Bandeira Duarte ${ }^{1 *}$, Joseneusa Brilhante Rodrigues ${ }^{2}$, Pedro Sérgio Estevam Ribeiro', \\ Jaime Estevão Scandolara ${ }^{2}$
}

\begin{abstract}
The area of study is located in the southwest of the Amazon Craton, northwest of Mato Grosso State and it comprises a region between Aripuanã and Juruena rivers. This paper proposes a geotectonic evolutionary model of a single continental magmatic arc for this Paleoproterozoic segment; its orogenesis starts around 1,820 Ma with subduction, oceanic plate consumption, crust generation followed by continental blocks oblique collision processes after approximately $160 \mathrm{Ma}$, resulting in the formation of the Juruena Magmatic Arc. The initial phase litotypes are represented by oceanic crust remnants from Bacaerí-Mogno Complex and sub-volcanic to volcanic rocks from Paranaíta Suite and Colíder Group respectively, which configures a marginal ridge. Southwestern, this belt is in contact with the Juruena Complex, a portion of the arc deformed in a ductile regime. This segment is composed by Vitória Suite, São Pedro and São Romão Granites and Vespor Mafic Suite. Volcanic rocks scattered in the complex, apparently filling retro-arc basins, are included in the Roosevelt Group. Post-collisional Type A granitogenesis, related to extensional tectonic, is represented by Serra da Providência Suite. The U-Pb LA-ICPMS geochronology results from two Paranaíta Suite samples, one Vitória Suite and one Vespor Mafic samples are 1,797 $\pm 14,1,769 \pm 17,1,783 \pm 14$ and 1,773 \pm 15 Ma, respectively. Ten rock samples were also examined by Sm-Nd method, resulting in $\mathrm{T}_{\mathrm{DM}}$ ages between 2.25 and $1.88 \mathrm{Ga}$ and $\varepsilon_{\mathrm{ND}(\mathrm{t})}$ values between $-1,9$ and $+1,92$. The isotopic results are compatible with the expected for the Juruena Magmatic Arc.
\end{abstract}

Keywords: Southwest Amazon Craton; Juruena Magmatic Arc; Geochronology.

Resumo Evolução tectônica do arco magmático Juruena entre os rios Aripuanã e Juruena: noroeste de Mato Grosso, Brasil. A área de estudo está localizada no SW do Cráton Amazônico, com a geologia inserida em um contexto orogenético convergente, que resultou na formação do Arco Magmático Juruena. O modelo proposto para este processo é de arco magmático continental único com início em aproximadamente $1.820 \mathrm{Ma}$, com processos de subducção, consumo de placa oceânica, geração de crosta e colisão obliqua de blocos continentais após aproximadamente 160 Ma. Os litotipos da fase inicial estão representados pelos resquícios de crosta oceânica do Complexo Bacareí-Mogno e pela faixa de rochas plutonovulcânicas deformadas em regime rúptil-dúctil. Esta, que configura uma cordilheira marginal, é composta pelos granitos da Suíte Paranaíta e vulcânicas do Grupo Colíder. A SW, este terreno esta em contato com o Complexo Juruena, deformado ductilmente. O segmento é formado pela Suíte Plutônica Vitória, pelos Granitos São Pedro e São Romão e pela Suíte Máfica Vespor. Rochas vulcânicas dispersas no complexo, aparentemente preenchendo bacias de retro-arco, são incluídas no Grupo Roosevelt. Granitogênese tipo A, pós-orogênica, relacionada à tectônica extensional esta representada pela Suíte Serra da Providência. Os resultados de geocronologia pelo método U-Pb LA-ICPMS de duas amostras da Suíte Paranaíta, uma amostra da Suíte Plutônica Vitória e uma amostra das Máficas Vespor foram 1.797 $\pm 14,1.769 \pm 17$, $1.783 \pm 14$ e $1.773 \pm 15 \mathrm{Ma}$, respectivamente. Também foram analisadas dez amostras pelo método Sm-Nd, resultando em idades $\mathrm{T}_{\mathrm{DM}}$ entre 2,25 a 1,88 Ga e valores de $\varepsilon_{\mathrm{ND}(\mathrm{t})}$ entre $-1,9$ a $+1,92$. Os resultados isotópicos são compatíveis com o esperado para o Arco Magmático Juruena.

Palavras-chave: Sudoeste do Cráton Amazônico; Arco Magmático Juruena; Geocronologia.

INTRODUCTION The area of study is located in the furthermost northwest of the Mato Grosso state, southwest of the Amazon Craton, roughly between Aripuanã and Juruena rivers (Fig. 1). It is of common knowledge that this region lacks of geological and geochronological information, mainly due to the difficulty of access. Historically, the works of Tassinari (1996), Sato \& Tassinari (1997) and Tassinari \&
Macambira (1999), which compiled the collection of geologic and isotopic data results available at the time, are the pioneers in arrange a geochronological and structural segmentation of the Amazon Craton in provinces and propose a mobile evolutionary tectonic model. These results have been continuously reviewed with more accurate U-Pb TIMS and SHRIMP geochronology data as can be seen in the works of

${ }^{1}$ Serviço Geológico do Brasil - CPRM, Superintendência Regional de Goiânia, Goiânia (GO), Brasil.

E-mail: tiago.duarte@cprm.gov.br, pedro.ribeiro@cprm.gov.br

${ }^{2}$ CPRM, Sede, Brasília (DF), Brasil. E-mail: joseneusa.rodrigues@cprm.gov.br, jaime.scandolara@cprm.gov.br

*Autor correspondente 
Cordani \& Teixeira (2007), Cordani et al. (2009) and Bettencourt et al. (2010).

In summary, by these authors, the early Archean stages comprised juvenile accretion that later culminate with the agglutination of successively younger crustal fragments, given rise to a large cratonic area in the early Mesoproterozoic. In this context, the study area is inserted in the Rio NegroJuruena province, containing rocks that cooled in the interval around $1.8 \mathrm{Ga}$ to $1.5 \mathrm{Ga}$. Alongside, also based in regional geochronology, Santos et al. (2002, 2008) proposed modifications in the nomenclature, geographic boundaries and age intervals in the previously established Amazon Craton Provinces.

In complement there are several less publicized regional geological survey works, accomplished by Klein et al. (2001), Souza et al. (2005), Scandolara (2006), Silva \& Abram (2008), Oliveira \& Albuquerque (2007), Souza \& Abreu (2007), Martin \& Abdallah (2007), Knust (2010), Alves et al. (2010) and Ribeiro \& Duarte (2010). These geological surveys are significant taking in account they have promoted the breakdown in geological mapping and stratigraphy. Besides, contain several Sm-Nd and $\mathrm{U}-\mathrm{Pb}$ geochronological results. Then, the main goal of this paper was to share in short the extensive data set of projects listed, mainly the Rio Aripuanã and Rio Guariba 1:250.000 geological survey, executed by Ribeiro \& Duarte (2010) and a set of new geochronological U-Pb LA-ICPMS and Sm-Nd analysis results from samples collected in the area of study.

REGIONAL GEOLOGY The field geology aspects and the geochronological results obtained from rocks samples collected in the area of study and vicinity permitted associate locally, the tectonic evolution in what was originally denominated by Souza et al. (2005) as Juruena Magmatic Arc and regionally as part of the Rondônia-Juruena Province. At the time, Santos et al. (2008) established that the Rondônia-Juruena Province was formed in the interval between 1,840 and 1,740 million years ago and divided it into two geologically distinct domains (Fig. 1). The Juruena Domain (1,848 to $1,793 \mathrm{Ma})$, in the east portion of the province, composed by plutonic units: Juruena Granodiorite $(1,848$ to $1,823 \mathrm{Ma})$, Paranaíta Suite $(1,819$ to $1,793 \mathrm{Ma})$ and BacaeríMogno Complex; rocks from a continental volcanicplutonic "andine" type arc, composed by intermediate and acid volcanic and volcanoclastic rocks from the Colíder Group (1,786 to 1,781 Ma), metatonalite and metagranodiorite from the Vitória Suite (1,785 to $1,775 \mathrm{Ma})$, metagranites São Pedro and São Romão (1,784 and 1,770 Ma, respectively) and orthogneiss from the Nova Monte Verde Complex (1,774 Ma). The Jamari Domain (1,760 to 1,740 Ma), in the west, shows a lithological combination typical of continental arc, with metaquartz-diorite, metatonalite, metagranodorite and metagabbro subordinate, from the Jamari Complex.

Based on recent geochronology data and according to the tectonic evolution model, the convergent orogenesis that shaped the Juruena Magmatic Arc (JMA) started in about 1,820 Ma ago. Compressive movements from SW to NE displaced an oceanic crust (Bacaerí-Mogno Complex) in the direction of the already cratonized Tapajós Magmatic Arc (TMA), resulting in plate subduction and consumption. The interaction between mantle and crustal sources in this accretionary environment generated hybrid magmas evidenced by rocks with $\varepsilon_{\mathrm{Nd}}$ values ranging slightly between negative and positive. In the area, the rocks related to the first stages of the subduction are arranged in the shape of a marginal ridge, composed by hypohabissal granites from Paranaíta Suite $(1,808$ to $1,769 \mathrm{Ma})$ and volcanic/volcanoclastic rocks from Colíder Group (1,803 to $1,766 \mathrm{Ma})$. This belt is found in tectonic contact with a medium to high grade degree metamorphic domain containing remaining fragments from oceanic crust denominated as Bacaerí-Mogno Complex ( $\mathrm{Sm}-\mathrm{Nd}$ isocron age 2.24 Ga $\left.\varepsilon_{\mathrm{Nd}(t)}+2.5\right)$ and predominantly plutonic rocks from Juruena Complex (1,787 to 1,764 Ma). This complex comprises the Vitória Suite $(1,787$ to 1,765 Ma), São Pedro (1,796 to $1,730 \mathrm{Ma})$ and São Romão (1,780 to $1,770 \mathrm{Ma})$ granites and the Vespor Mafic Suite (1,773 to 1,764 Ma). Disperse volcanic rocks in the complex, apparently filling retro arc type basins are included in the Roosevelt Group (1,772 to $1,740 \mathrm{Ma}$ ). The geological episode that imprints the high grade deformation in the JMA is the collisional Quatro Cachoeiras orogen (Rizzotto et al. 2004). In the southwest of the area, closer to the suture, this orogen is identified by metamorphic ages around 1,640 Ma, obtained in overgrowth zircon rims in samples from Jamari Complex (RO) and also by rocks metamorphosed in granulite facies. After, in the Mesoproterozoic, occurs the post-collisional JMA granitogenesis from Serra da Providência Suite $(1,605$ to $1,505 \mathrm{Ma})$. Other geological event recorded in 
stratigraphy is the Mesozoic mafic dikes from Central Atlantic Magmatic Province (Marzoli et al. 1999) and the intrusion of narrow mafic bodies in the Cretaceous.

Fig. 2 presents the geotectonical map from the surrounds of the studied area. It shows the spatial arrangement between the lithostratigraphic units and established an approximated limit between the JMA and TMA.

\section{GEOLOGICAL EVOLUTION AND}

LITHOSTRATIGRAPHIC Field work, plus petrographic, geochemistry and isotopic analyses allied with the interpretation of high resolution airborne gammaspectrometry and magnetometry geophysics allowed this work to consolidate a refined geological map and a tectonic-stratigraphic framework in relation to the previous works available in 1:1,000,000 scale (Rizzotto et al. 2004). The Figs. 3A, B and C present an 1:250,000 geological map, the tectonicstratigraphic framework and a schematic geological profile for the area of study.

The most ancient rocks mapped in this region are from Bacaerí-Mogno Complex. They are considered as remains of an oceanic crust and associated terrigenous material that subducted under the TMA cratonized crust. Were identified several peraluminous rocks as sillimanita-cordierite gneiss/migmatite, sillimanita-garnet

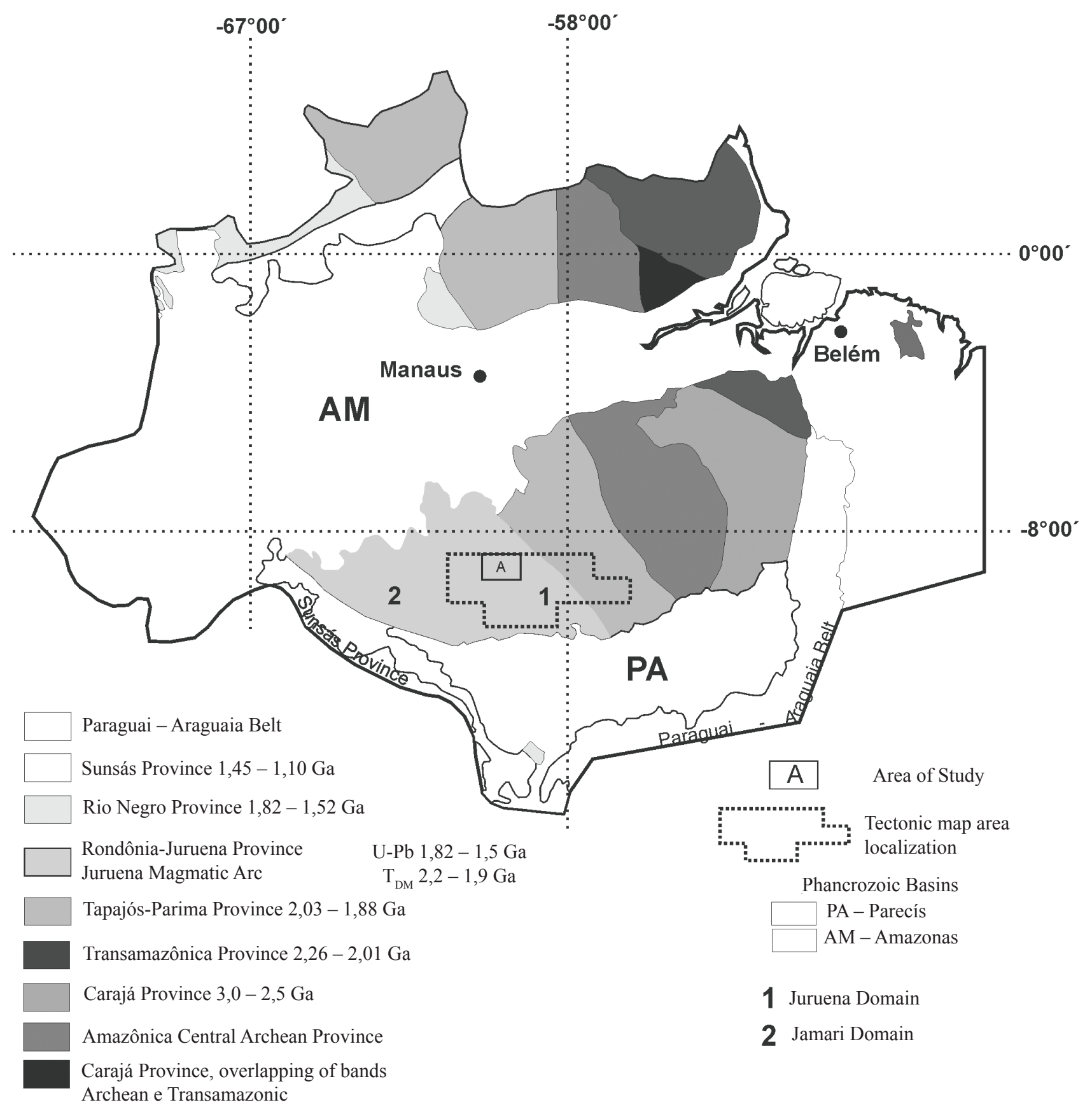

Figure 1 - Amazon Craton Geochronological Provinces modified from Santos et al. (2008). The A polygon represent the SC.21-V-C Rio Aripuanã quadrangle and the dotted polygon the geotectonic map area. 
gneiss/migmatite and calc-silicatic rocks. Outcrops from these litotypes are scattered throughout the Juruena Complex. In the northeast of the area the outcrops are from volcanic/volcanoclastic and associated hypo-abyssal granites. Regionally, it configures a marginal ridge with approximately 50 kilometers width with 600 kilometers in length, bordering the north of Mato Grosso State, since Peixoto de Azevedo until the vicinity of Apuí, in Amazonas State. This belt is interpreted as a marginal ridge developed along the border of the Tapajós crust. The litotypes identified are riolite, dacite, andesite and volcanoclastic rocks with primary depositional features preserved from Colíder Group and hypo-abyssal monzo/sienogranite and granodiorite from Paranaíta Suite. In Ribeiro \& Duarte (2010), rock analysis chemical results showed in tectono-magmatic discrimination diagrams that the parental magma of these rocks have mantle derivates affinities and crustal contamination calc-alkaline, colisional type magmatism characteristics. These units isotopic data set displays a range of $\varepsilon_{\mathrm{Nd}(\mathrm{t})}$ from -3.06 with $\mathrm{T}_{\mathrm{DM}} 2.78 \mathrm{Ga}$ to $\varepsilon_{\mathrm{Nd}(\mathrm{t})}+1.79$ with $\mathrm{T}_{\mathrm{DM}} 1.94 \mathrm{Ga}$, results that also indicate that this magmas source have originated from a mixture of juvenile material with ancient recycled continental crust. The crystallization ages available for these units vary almost equally for both of them and are between 1,803 \pm 3 and 1,766 \pm 5.7 Ma in the Colíder Suite and 1,808 \pm 14 to $1,769 \pm 5.7 \mathrm{Ma}$ in the Paranaíta Suite. These results show a volcano-plutonism period of approximately 40 million years.

In tectonic contact and relatively contemporary to the plutonic-volcanic belt are a medium to high

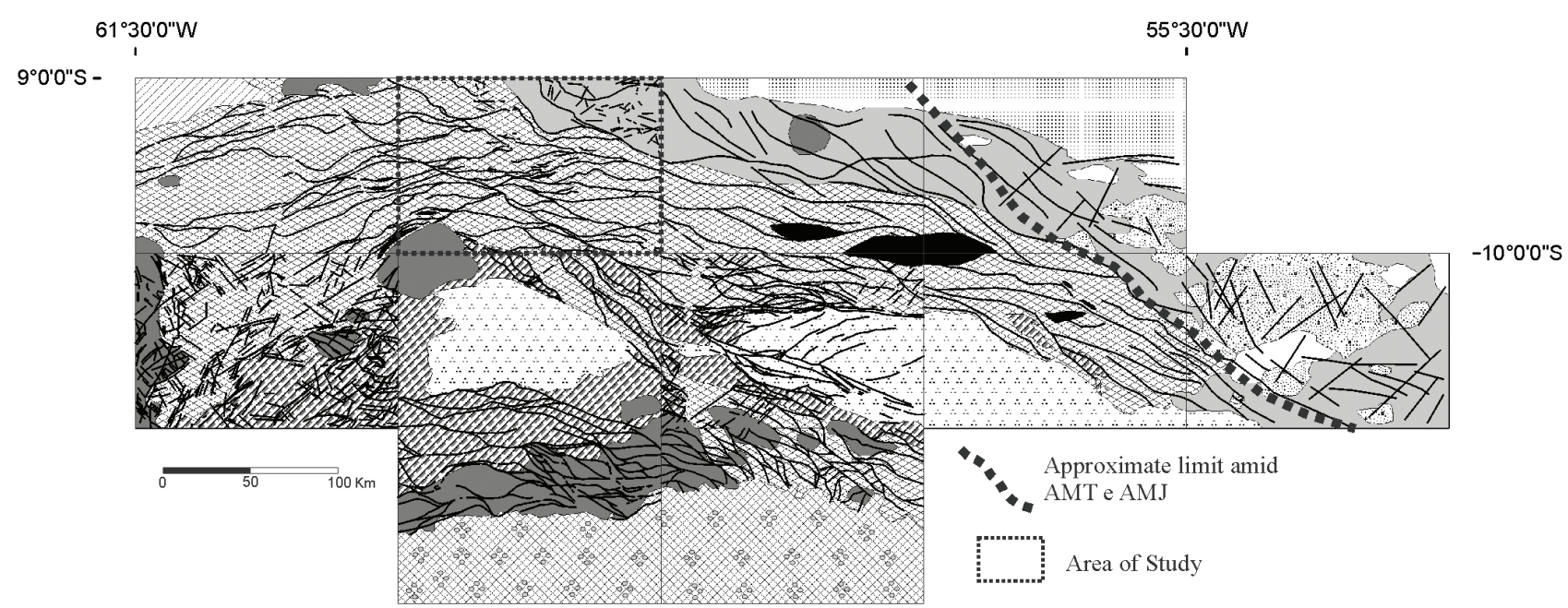

\footnotetext{
Paleozoic
}

Palmeiral Formation Tonian

Dardanelos Formation Calymnian

\section{Juruena Magmatic Arc (JMA)}

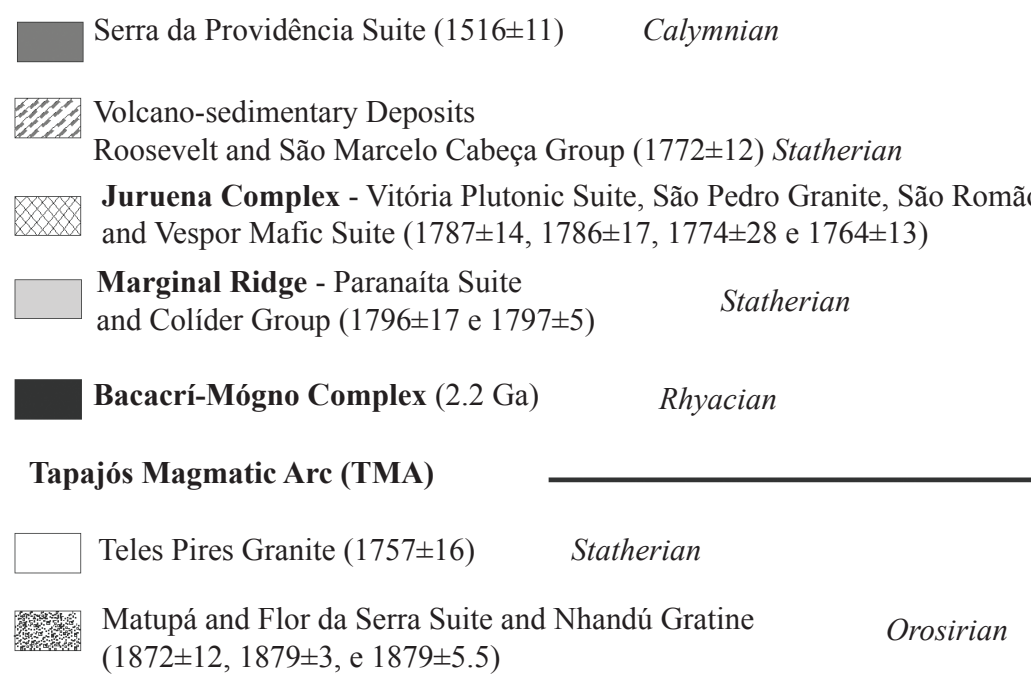

Figure 2 - Geotectonic map from the surrounds of the studied area. The dotted line represents the approximate limit between the Tapajós and Juruena Magmatic Arcs. 
grade metamorphosed group of rocks, crystallized at deeper depths. They represent the root of the JMA and compound the Juruena Complex. The usage of the term complex was proposed to cluster lithostratigraphic units with petrogenetic affinities, complex spatial disposition and crystallization and model ages around 1,775 and 2,050 Ma, respectively. The units of Juruena Complex are the Vitoria Plutonic Suite, São Pedro and São Romão granites and the Vespor Mafic Suite. The Vitoria Plutonic Suite includes metaluminous high-K calc-alkaline; metadiorite, metagranodiorite, metaquartz-diorite and metatonalite with crystallization ages varying between 1,787 \pm 14 and 1,765 $\pm 4 \mathrm{Ma}$. São Pedro and São Romão granites include high-K, aluminous calc-alkaline metamonzogranites and metasienogranites, with crystallization ages between 1,786 \pm 17 and 1,770 + -9 Ma. They differ from each other in relation to distinct metamorphic textures. The São Pedro Granite has a porfiroclastic texture while the São Romão Granite has a fine foliated one. The unit Vespor Mafic Suite was established to encompass a series of mafic rock stocks and batholiths. The type section is located at Vespor farm, district of Colniza, Mato Grosso state. It includes metagabbro, metadiorite and amphibolite with tholeiitic affinity and magmatic arc signature.
Two samples were dated by U-Pb LA-ICPMS resulting in crystallization ages of $1,773 \pm 15$ and 1,764 \pm $13 \mathrm{Ma}$ (Ribeiro \& Duarte 2010).

With scattered occurrence, volcanic rocks in the Juruena Complex are related to the Roosevelt Group Metavolcanic Unit (Oliveira \& Albuquerque 2007). The rocks are pyroclastic (lapilli-tuff crystaltuff) and effusive (riolite and riodacite). Chemical analysis in these rocks shows high-K and calc-alkaline tendency. Also, tectonic discrimination diagrams suggest a colisional arc generation environment related to back-arc basins (Ribeiro \& Duarte 2010). The crystallization ages available for the unit are between $1,772 \pm 12$ and $1,740 \pm 8 \mathrm{Ma}$.

After a hiatus of approximately $100 \mathrm{Ma}$, the JMA post-collisional period is evidenced by the extensive Serra da Providência Suite magmatism. This unit gathers monzogranite and sienogranite with rapakive texture. Chemically the rocks are sub-alkaline with high to very high-K and A2-type granite signature. A substantial data set of U-Pb crystallization ages results are available for this unit, and reveals a range of ages between $1,606 \pm 24$ and 1,505 $\pm 9.8 \mathrm{Ma}$, characterizing a 100 million years magmatism period.

In the end of the Mesoproterozoic, an extensional period related to the Sunsás-Aguapeí Orogen
A) Simplified Geological Map

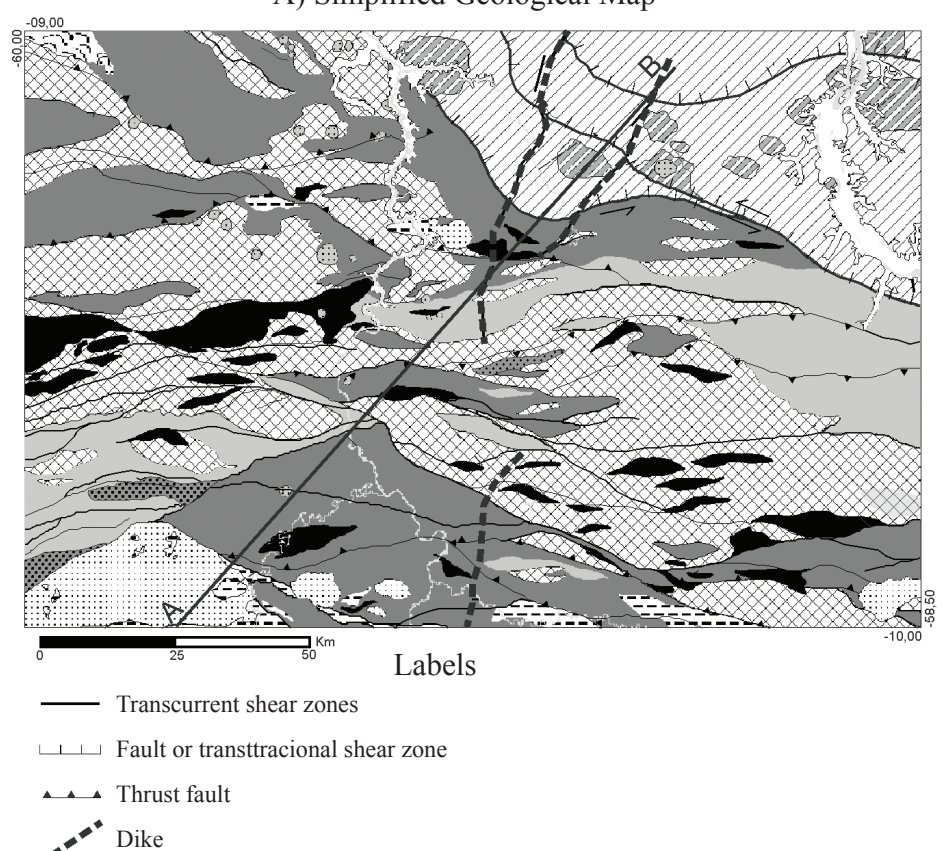

B) Tectono-Stratigraphic Chart

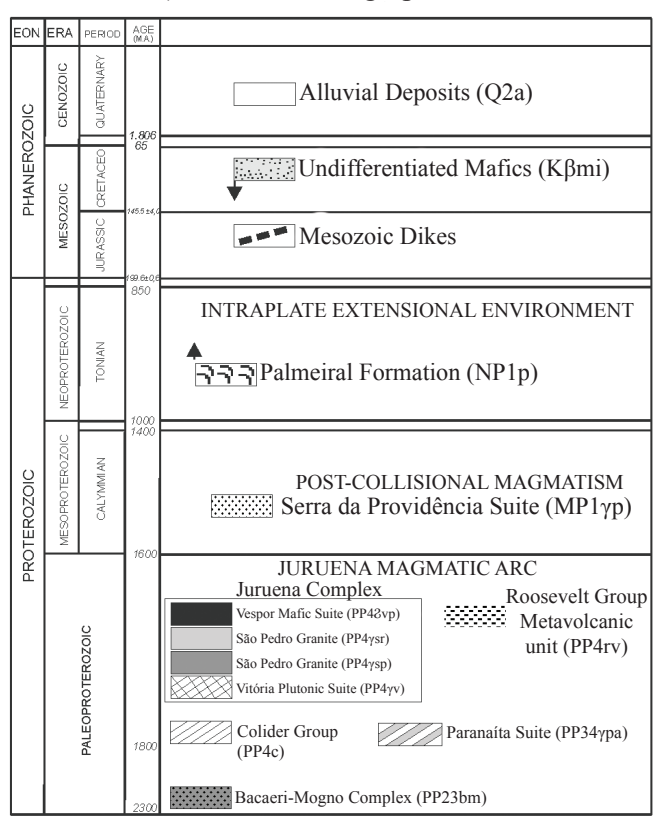

C) Cross Section A-B

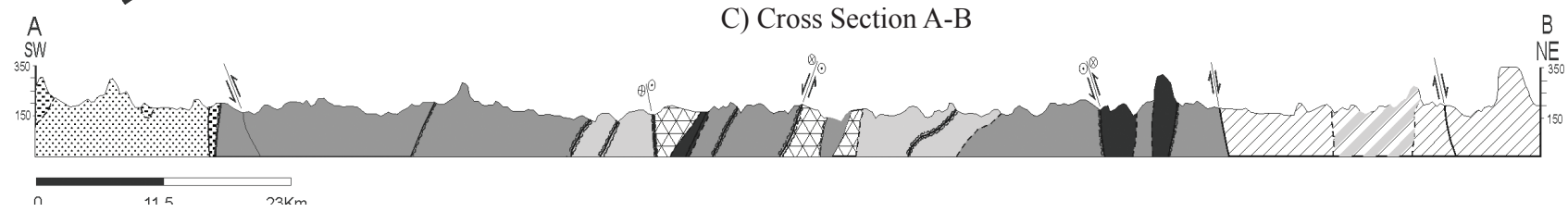

Figure 3 - (A) Geologic map from the area of study, (B) tectonic-stratigraphic framework and (C) geologic profile. 
is established. This event determined the formation of graben type basins and deposition of Palmeiral Formation sediments. The litotypes that compose this unit are basically immature conglomerate and sandstone. The outcrops are typical, forming plateaus easily identified through remote sensing. K-Ar geochronology done by Leal (1978), in basalt from Nova Floresta Formation intruded among the sediments, reveals the ages between $967 \pm 17$ and 1,098 $\pm 17 \mathrm{Ma}$.

The Phanerozoic units found are Mesozoic dikes, undifferentiated mafic rocks and alluvial deposits. The dikes directions are N-S to N-E; they are associated with a 200 Ma old extensive magmatism from the Central Atlantic Magmatic Province (Marzoli et al. 1999). The term undifferentiated mafic rocks was used to classify informally small aeromagnetic analytic signal dipolar anomalies. It was important to cartography these anomalies due to the possibility of relation with the Cretaceous kimberlitic cluster called Madeirinha, located in the Rio Guariba quadrangle. Finally the Holocene alluvial deposits cover unconsolidated sediments as clay, sand and gravel found optimally in channels and margins from the main drainages.

\section{STRUCTURAL}

\section{GEOLOGY}

AND

METAMORPHISM The analysis of radar and aeromagnetic remote sensing products, associated with field data allowed the delimitation of three structural domains in the area of study: ductile, ductile-brittle and brittle domains. Fig. 4 shows the area map with the representation of the domains and interpreted magnetic alignments.

The Ductile domain covers approximately $70 \%$ of the area and it is composed by the BacaeríMogno and Juruena Complex. This domain structural framework was interpreted as the result of a single progressive accretionary event, syngenetic with the JMA evolution. Structural analysis shows three stages of deformation. The first one, $\mathrm{D}_{1}$ has the compressional vector $\mathrm{s}_{1}$ position at approximately E-W, is characterized by regional N-S gneissic banding $\left(\mathrm{S}_{\mathrm{n}}\right)$. In the second stage $\mathrm{D}_{2}$ the $\mathrm{s}_{1}$ vector rotates $180^{\circ}$ degrees to N-S. This shift is evidenced by isoclinal folds $\left(\mathrm{S}_{\mathrm{n}+1}\right)$ with E-W axial planes. In the third stage $\mathrm{D}_{3}$, there is a slightly shift in the $\mathrm{s}_{1}$ direction to east and the generation of sinistral shear zones $\left(\mathrm{S}_{\mathrm{n}+2}\right)$ parallel to the $S_{n+1}$ folds axial planes. Fig. 5 presents outcrops pictures and schemes for illustrate the event sequences described above.

The peek metamorphic degree in the ductile domain was estimated as amphibolite to high amphibolite facies based on the presence of ductile structures (gneissification and initial migmatitization) and mineral paragenesis rich in garnet, sillimanite predominantly and cordierite. Also, the crustal shortening entailed by the progressive deformation caused the exhumation of this domain of rocks to shallower crust levels and subsequent rebalance of the metamorphic degree to green schist facies, with biotite and

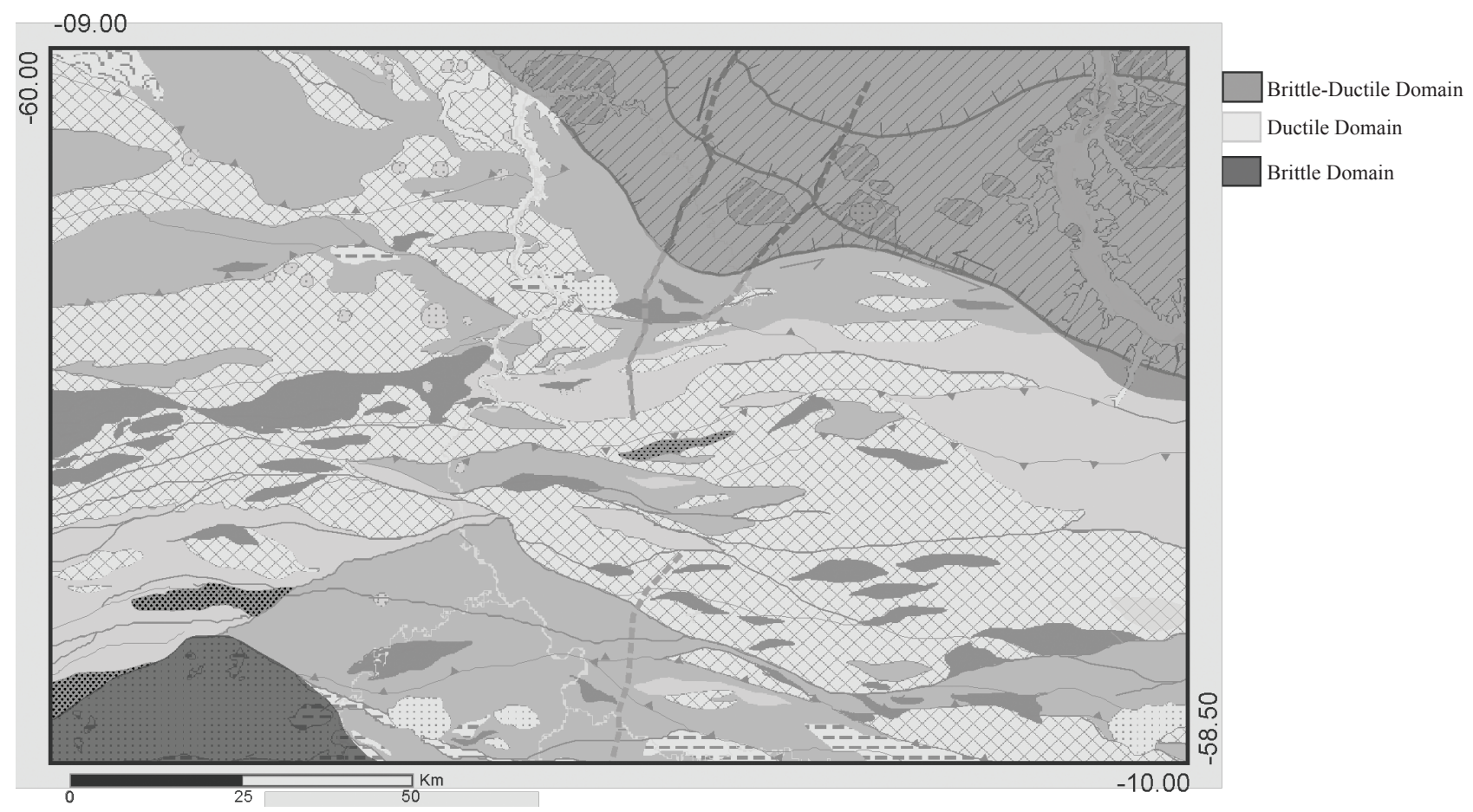

Figure 4 - Structural domains delimited in the area of study. 
epidote in substitution of amphiboles. Few U-Pb IDTIMS results in the area reveal what is considered the peek metamorphism age. A proto-mylonite from São Pedro Granite was dated in 1,669 \pm 6 Ma by Souza et al. (2005) and a granodiorite gneiss from Vitória Suite in 1,669 \pm 7 Ma by Pinho et al. (2003). West of the area, in Rondônia State, a similar mean age of 1,664 Ma was calculated using the results of more accurate U-Pb SHRIMP analyses from metamorphic zircons overgrowth rims published by Santos et al. 2008. These results, in the mean of 1,660 Ma, are related in this work to the Quatro Cachoeiras colisional phase defined by Rizzotto et al. 2004.

The Ductile-Brittle domain is composed by the volcanic-plutonic belt, located at the northeast of the area. There, the structural features commonly observed in outcrops are sets of fractures associated with sinistral shear zones. These sets of fractures and shear zones were analyzed individually based on the RIEDEL model for brittle regime deformations.
The results indicate that the compression direction $\mathrm{s}_{1}$ ranged between $\mathrm{N} 45^{\circ} \mathrm{E}$ and $\mathrm{E}-\mathrm{W}$. Unlike the ductile domain, only $\mathrm{D}_{3}$ transcurrent stage was printed in the rocks from this domain.

The Brittle domain delimitate extensive areas were lithostratigraphic units younger than the deformation stages listed above occur. It is the case of Serra da Providência Suite and Palmeiral Formation sediments where only indiscriminate fractures and preserved sedimentary structures were described.

GEOCHRONOLOGY The radiometric datings were performed in the Laboratory of Geochronology of Universidade de Brasilia. The analyzed samples were collected by Ribeiro \& Duarte (2010) and selected based in two distinct factors. The first considered the sample's importance for understanding the region lithostratigraphic stacking and the second took in account the absence of previous data. Five samples were analyzed for U-Pb LA-CPMS in zircon
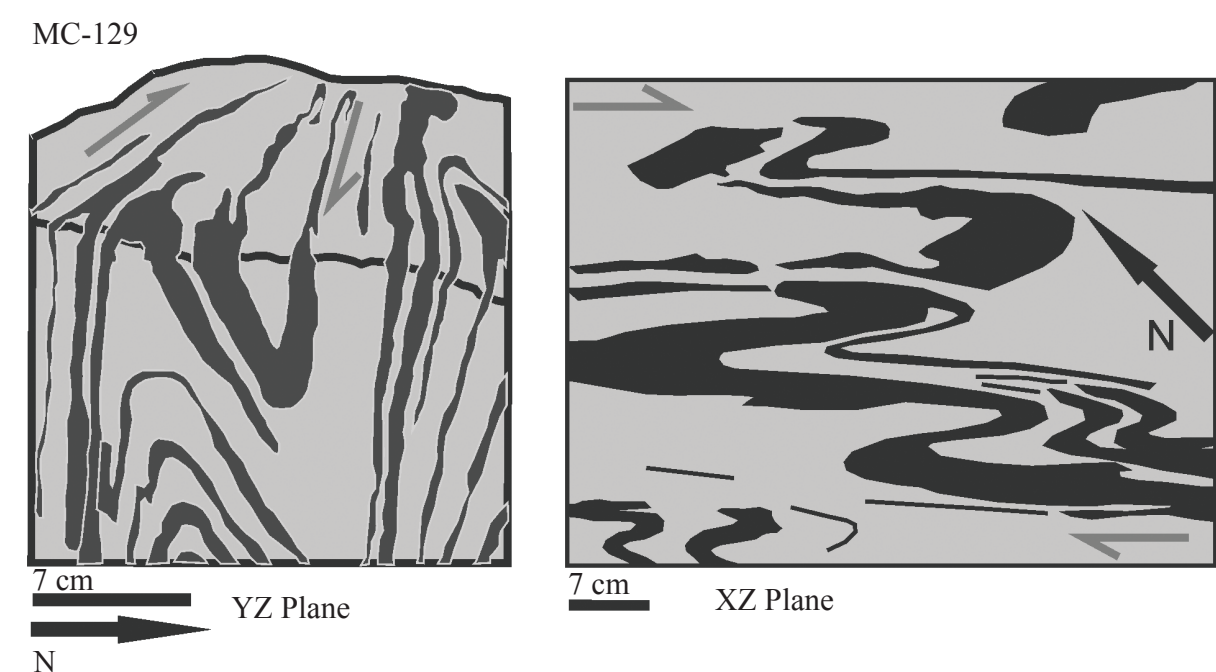

D1-Gneiss bands Sn N-S (б1=E-W)

D2-Isoclinical Folds $\mathrm{Sn}+1$ Axial Planes E-W (61=N-S)

D3-Axial Plane Shear

$\left(\mathrm{Sn}+2 \mathrm{~N} 45^{\circ} \mathrm{W} /\right.$ Subvertical $)$

Parallel to the folds axial planes Dextral Drive

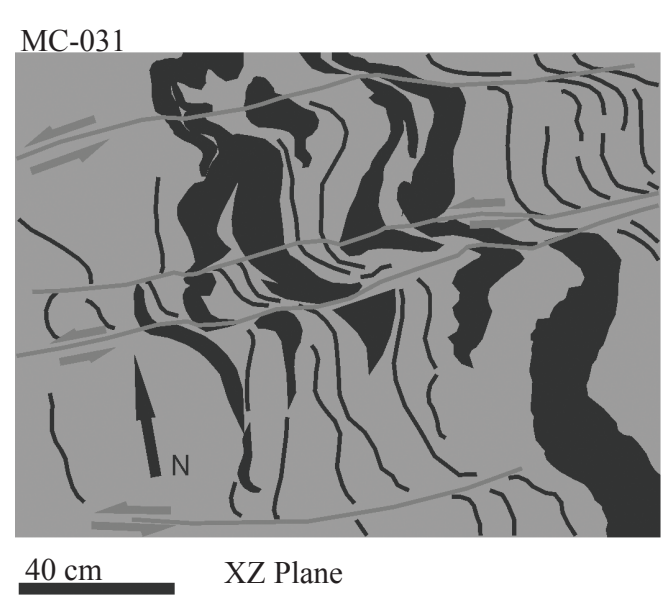

D1-Gneiss Bands Sn N05 ${ }^{\circ} \mathrm{W}$ $\left(61 \sim \mathrm{N} 85^{\circ} \mathrm{E}\right)$.
D2-Isoclinal Folds $\mathrm{Sn}+1$ $\mathrm{N} 80^{\circ} \mathrm{E} /$ Subvertical $\left(61 \sim \mathrm{N} 10^{\circ} \mathrm{W}\right)$.

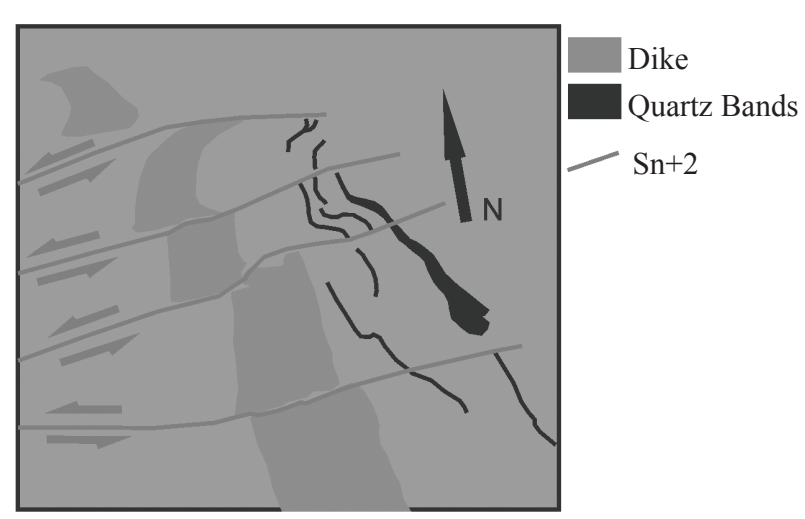

XZ Plane $30 \mathrm{~cm}$

Figure 5 -Sketch of outcrops from the ductile domain that illustrate the three stages of progressive deformation $\left(D_{1}, D_{2}\right.$ and $\left.D_{3}\right)$. 
and ten for Sm-Nd total rock (Tab. 1). The analytical results for each sample are summarized in the Tab. 2 .

\section{U-Pb laser ablation inductively coupled plasma} mass spectrometry methodology The procedure for concentrate zircon and monazite crystals was reducing the sample in a crusher and take out the fraction lower than $500 \mu \mathrm{m}$; the heavy minerals from this fraction were then concentrated panning. In the next step, the material was passed through the Frantz isodynamic separator and finally the zircon and monazite crystals were handpicked using a binocular magnifier. The mounts were made with cold epoxy resin, worn and polished to expose the crystals interior. The mounts were cleaned in a nitric acid bath $(3 \%)$, Nanopure ${ }^{\circledR}$ water in ultrasound and acetone for the extraction of any moist residue. The analytical equipment utilized was a Multi-Collector Inductively Coupled Plasma Mass Spectrometry MC-ICP-MS Neptune (Thermo-Finnigan) coupled to Nd:YAG $(1=213 \mathrm{~nm})$ Laser Ablation System (New Wave Research, USA). The analytical procedure was described by Bunh et al. (2009) and basically consists in the laser ablation of crystals in 25 to $40 \mu \mathrm{m}$ spots, 9 to $13 \mathrm{~Hz}$ frequency and 0.19 to $1.02 \mathrm{~J} / \mathrm{cm}^{2}$ intensity. The powdered material is adduced by $\mathrm{He}$ flux $(\sim 0.40 \mathrm{~L} / \mathrm{min})$ and $\operatorname{Ar}(\sim 0.90 \mathrm{~L} / \mathrm{min})$. In every analysis the international standard addition GJ-1 and the TEMORA or intern laboratory standard PAD-1 were utilized. The data was acquired in 40 cycles of 1 second and the reading sequence was 1 blank, 1 standard, 4 samples, 1 blank and 1 standard. In each reading the mass intensity of ${ }^{202} \mathrm{Hg},{ }^{204}(\mathrm{~Pb}+\mathrm{Hg}),{ }^{206} \mathrm{~Pb}$, ${ }^{207} \mathrm{~Pb},{ }^{208} \mathrm{~Pb}$ and ${ }^{238} \mathrm{U}$ was determined. The raw data reduction, including blank corrections, equipment deviation and common led were performed in the laboratory's own Excel spreadsheet. The ratios uncertainties presented in the Tab. 2 are $1 \mathrm{~s}$, in percent. The ages were calculated using the software Isoplot 3.0 (Ludwig 2003).

Samarium-Neodymium methodology The Sm$\mathrm{Nd}$ isotopic analyses followed the methodology described by Gioia \& Pimentel (2000). In this procedure, approximately $50 \mathrm{mg}$ of powdered sample was mixed with a tracer solution of ${ }^{149} \mathrm{Sm}$ and ${ }^{150} \mathrm{Nd}$. The sample is dissolved in Savillex ${ }^{\circledR}$ capsules through successive $\mathrm{HF}, \mathrm{HNO}_{3}$ and $\mathrm{HCl}$ attacks. The $\mathrm{Sm}$ and $\mathrm{Nd}$ contents were extracted through cationic exchange columns, made with Teflon and filled with LN-Spec. resin. The Sm and Nd salts are deposited in rhenium filaments with nitric acid and evaporated. The ratios readings were performed in a multicollector mass spectrometer, model Finnigan MAT 262 in static mode. The ${ }^{147} \mathrm{Sm} /{ }^{144} \mathrm{Nd}$ and ${ }^{143} \mathrm{Na} /{ }^{144} \mathrm{Nd}$ ratios uncertainties are less than \pm 0.55 (2s) and $\pm 0.0055(2 \mathrm{~s})$ respectively, based in repeated analysis in the international standards BHVO-1 and BCR-1. The ${ }^{143} \mathrm{Nd} /{ }^{144} \mathrm{Nd}$ ratio was normalized in function of ${ }^{146} \mathrm{Nd} /{ }^{144} \mathrm{Nd}$ ratio equals to 0.7219 . The $\mathrm{T}_{\mathrm{DM}}$ values were calculated using the DePaolo (1981) model.

\section{RESULTS}

\section{U-Pb laser ablation inductively coupled plasma} mass spectrometry methodology Five rock samples distributed among Vitória Plutonic Suite, Vespor Mafic Suite and Paranaíta Suite were selected for U-Pb. The analytical results are presented in Tab. 2.

Sample MC-027Aa is from a tonalitic composition band from a Suite Vitória layered gneiss. The zircons extracted present a unique morphological

Table 1 - Localization coordinates, petrographic classification and lithostratigraphic units from the samples selected for U-Pb LA-ICPMS and Sm-Nd isotopic analysis

\begin{tabular}{lcccccc}
\hline Sample & Zone & UTM E & UTM N & Analysis & Petrography & Unit \\
\hline MC-002 & 21S & 174028 & 8966966 & Sm-Nd & Metamonzogranite & São Pedro Granite \\
\hline TD-137 & $21 \mathrm{~S}$ & 232115 & 8984950 & Sm-Nd & Metamonzogranite & São Pedro Granite \\
\hline MC-017 & $21 \mathrm{~S}$ & 268825 & 8990704 & $\mathrm{Sm}-\mathrm{Nd}$ & Metadacite & Colíder Group \\
\hline $\mathrm{MC}-058$ & $21 \mathrm{~S}$ & 218666 & 8893681 & $\mathrm{Sm}-\mathrm{Nd}$ & Metariodacite & Roosevelt Group \\
\hline $\mathrm{MC}-120$ & $21 \mathrm{~S}$ & 289931 & 8983445 & $\mathrm{U}-\mathrm{Pb}$ and Sm-Nd & Metamonzogranite & Paranaíta Suite \\
\hline $\mathrm{MC}-140$ & $21 \mathrm{~S}$ & 333344 & 8918063 & $\mathrm{Sm}-\mathrm{Nd}$ & Porfiry Monzogranite & Paranaíta Suite \\
\hline $\mathrm{TD}-151$ & $21 \mathrm{~S}$ & 246883 & 9000649 & $\mathrm{U}-\mathrm{Pb}$ & Porfiry Sienogranite & Paranaíta Suite \\
\hline $\mathrm{MC}-027 \mathrm{Bb}$ & $21 \mathrm{~S}$ & 283397 & 8939543 & $\mathrm{U}-\mathrm{Pb}$ and Sm-Nd & Metagabbro & Vespor Mafic Suite \\
\hline $\mathrm{MC}-027 \mathrm{Bb}$ & $21 \mathrm{~S}$ & 265686 & 8958090 & $\mathrm{U}-\mathrm{Pb}$ and Sm-Nd & Metatonalite & Vitória Plutonic Suite \\
\hline TD-048B & $21 \mathrm{~S}$ & 265686 & 8958090 & $\mathrm{U}-\mathrm{Pb}$ & Anfibolite & Vitória Plutonic Suite \\
\hline TD-034A & $21 \mathrm{~S}$ & 185257 & 8896746 & $\mathrm{Sm}-\mathrm{Nd}$ & Metamonzogranite & Serra da Providência Suite \\
\hline
\end{tabular}




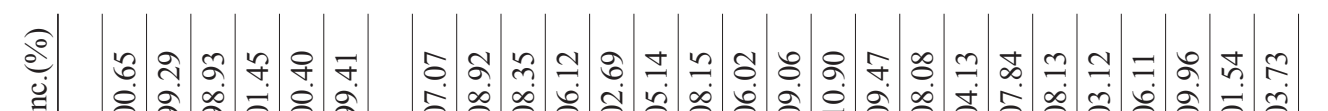

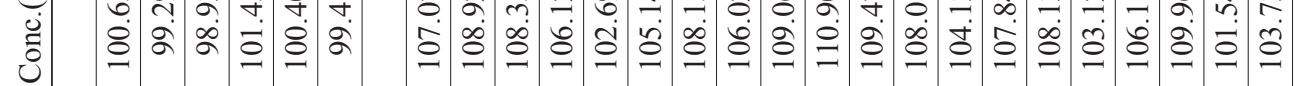

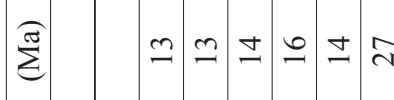

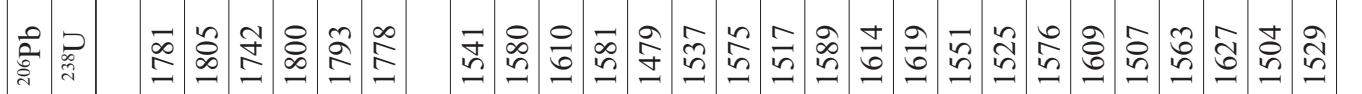

事

㲅

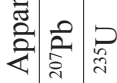

§

ㅇํㅇำ

용

帘:

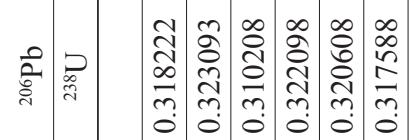

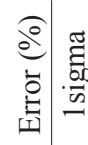

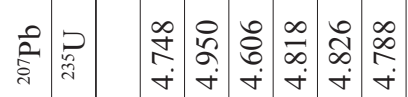

量

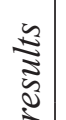

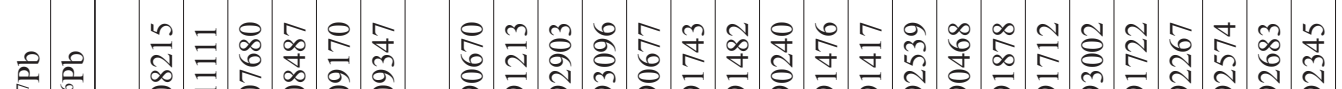
畜

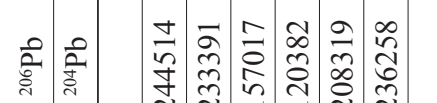

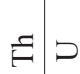

这

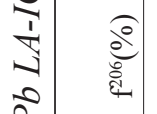

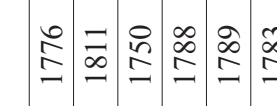

$\simeq \cong \pm \cong=$

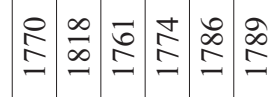

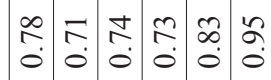

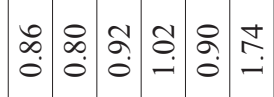

닥 $\begin{gathered}a \\ 0 \\ 0\end{gathered}$

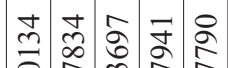

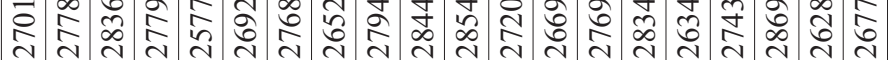

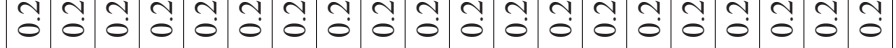

a

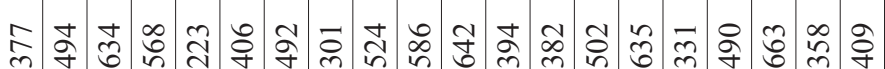

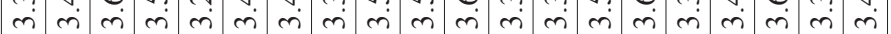

के ț

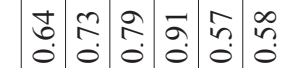

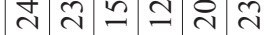
它

$\underset{\substack{1 \\ \infty}}{\substack{2 \\ \infty}}$

$\underset{n}{\mathbb{N}}$

în

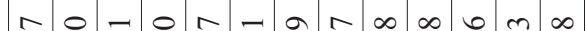

N.

$\begin{array}{lllllll}0 & 0 & 0 & 0 & 0 & 0\end{array}$

$\ddot{0}$

-

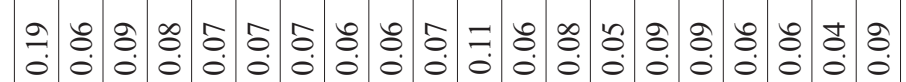

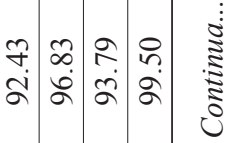

$\simeq \cong$

๗ి

$\infty$ 으 $=$ n

g으를 을

$= \pm \stackrel{n}{2}$

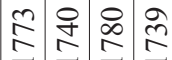

$\stackrel{2}{2} \underset{0}{\infty}$

ஸి

苞늠

๙ิ)

¿.

กำำำ

సิ

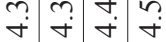

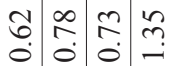

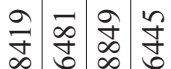
\& $\begin{array}{llll}0 & 0 & 0 & 0\end{array}$

후 诰 ชู่

ఫ.

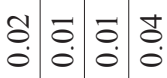

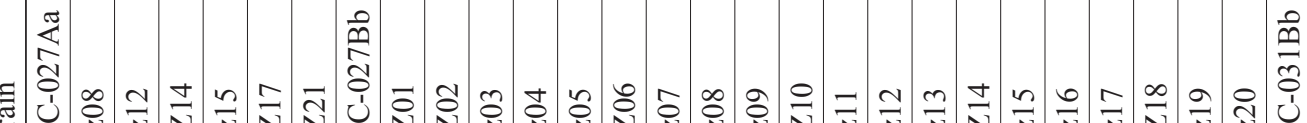

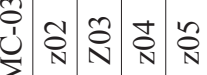




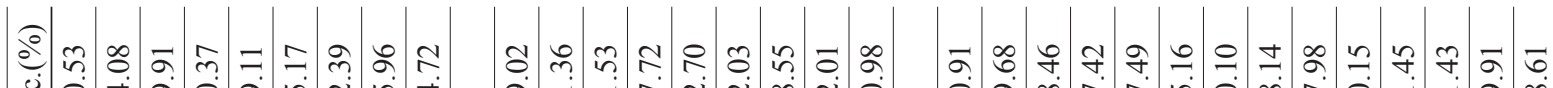

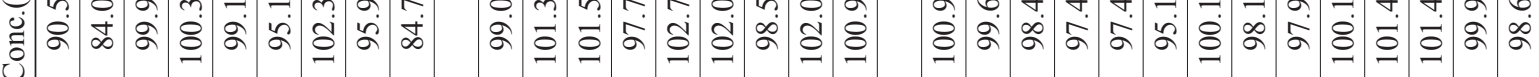

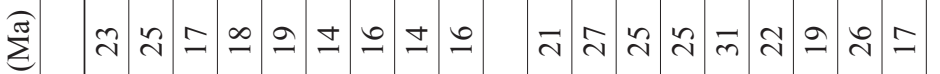

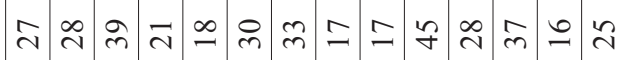

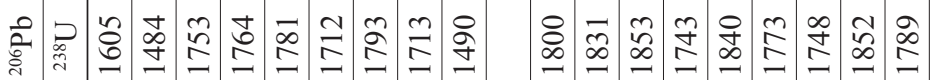

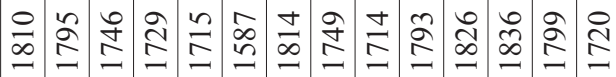

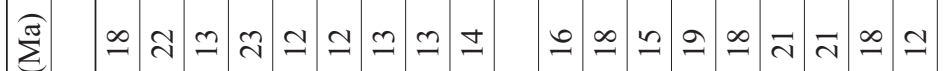

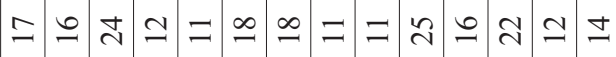

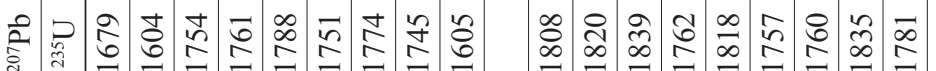

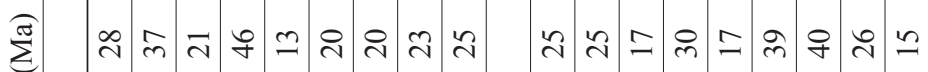

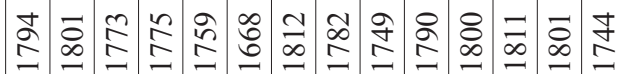

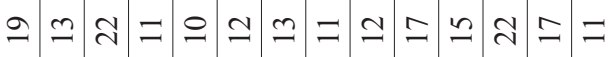

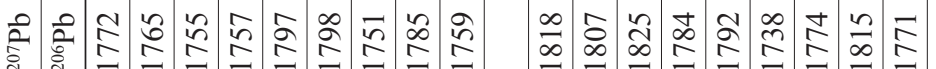

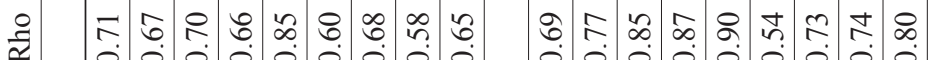

돈

竞

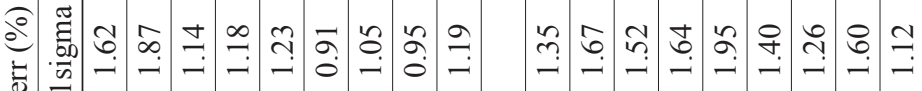

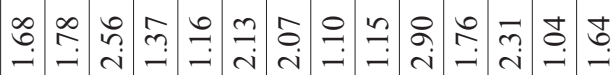

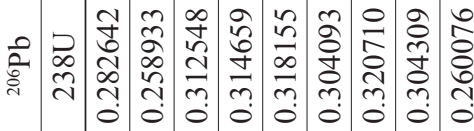

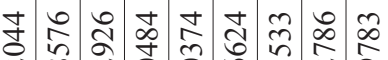

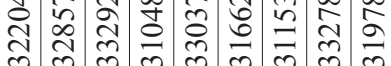

๗઼.

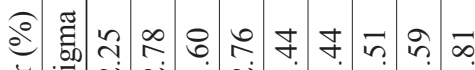

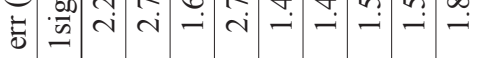

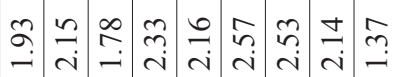

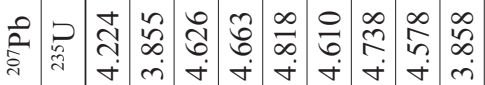

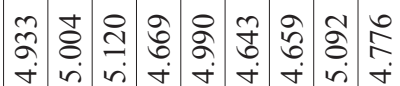

สี นินี่

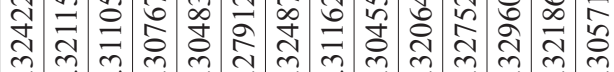
?.:

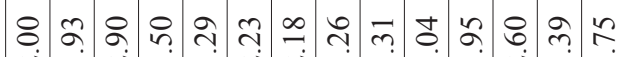

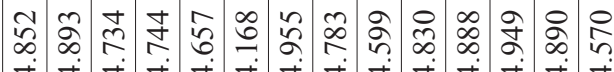

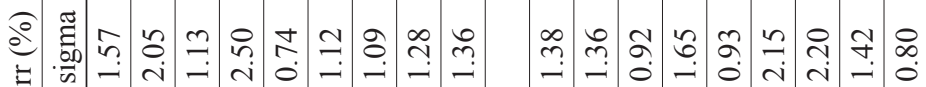

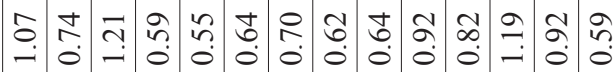

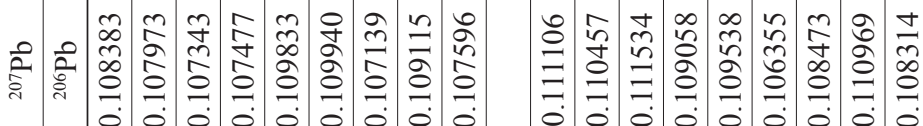

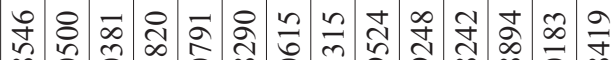
定

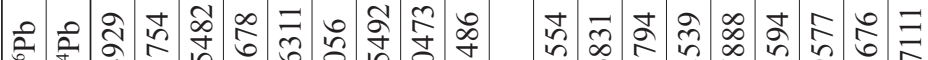

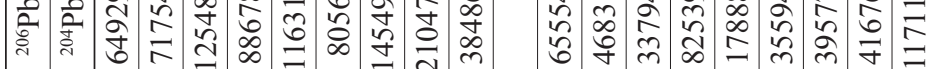

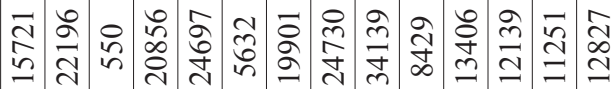

₹

m

อ

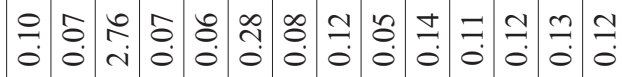

을

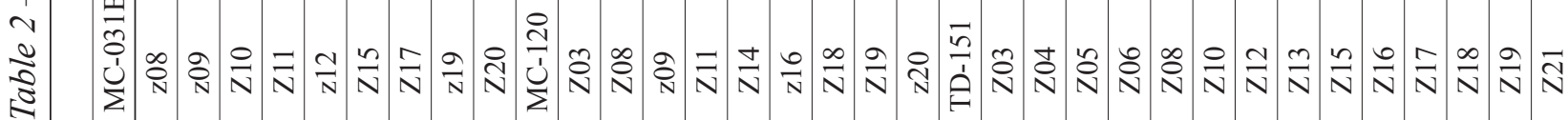


pattern. They are median sized, bipyramidal, long, colorless, limpid and have prismatic habit. Twenty crystals were analyzed and presented ${ }^{207} \mathrm{~Pb} /{ }^{206} \mathrm{~Pb}$ between 1,736 and 1,818 Ma. All crystals have low contents of common lead and the $\mathrm{Th} / \mathrm{U}$ ratios are similar to those found in zircons from igneous source. Data from six crystals with more consistent results were utilized to calculate a concordia age of $1,783 \pm 14 \mathrm{Ma}$ with MSWD $=0.001$ (Fig. 6). This result is considered as the crystallization age of the magma body.

Sample MC- $027 \mathrm{Bb}$ is from an amphibolitic enclave restrained in a Suite Vitória layered gneiss. The zircon population extracted from this sample is quite homogeneous, composed by round, colorless and limpid short prismatic crystals. Every twenty crystals analyzed presented low $\mathrm{Th} / \mathrm{U}$ ratios, low contents of common lead and a varying degree of reverse discordance. The concordia calculated with all analytical results showed an upper intercept of 1,439 $\pm 39 \mathrm{Ma}$ (Fig. 7). This age clash with the spectrum of crystallization ages expected. The low $\mathrm{Th} / \mathrm{U}$ ratios are typical of metamorphic crystals and so the result may represent an age of isotopic re-equilibrium associated with a high temperature metamorphic event previously unnoted in the area of study.

Sample MC-031Bb is from a Vespor Mafic Suite meta-gabbro dike of approximately $60 \mathrm{~cm}$ width. The dike is intrusive in proto-mylonitic gneiss from the Vitória Suite. This sample provided colorless to yellowish small to medium sized zircon crystals, with a few fractures and inclusions. Twenty crystals were selected to analysis, however seven of them were not used because they presented instable analytical signal. The remaining data results presented a small lead lost and were used to calculate an upper intercept concordia of $1,773 \pm 15$ Ma (Fig. 8).

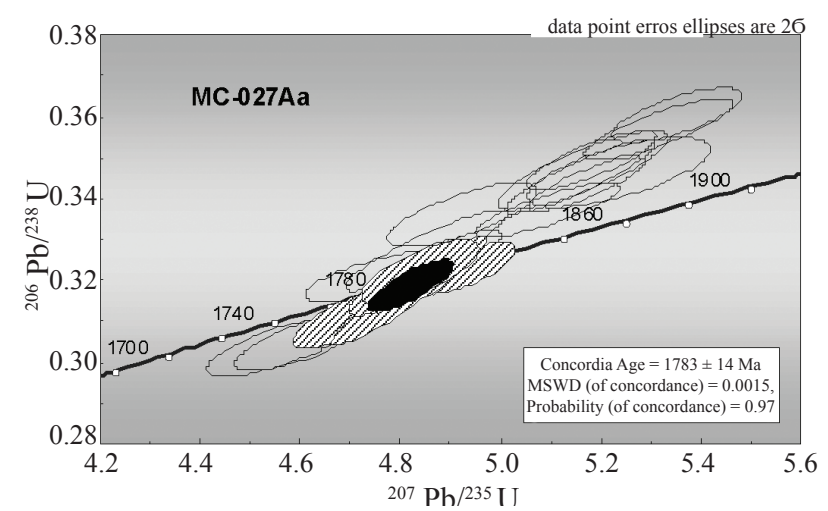

Figure $6-$ MC-027Aa concordia diagram. The empty circles represent discordant spots, not used in the age calculation.
This result is interpreted as the crystallization age. It is noteworthy that this is the first age of crystallization calculated for the Vespor Mafic Suite.

Sample MC-120 is from a Paranaíta Suite meta-monzogranite. The zircons crystals extracted from this sample are small, with prismatic bipyramidal habit, colorless to sallow, clear and with a few fractures. At total 18 zircon crystals were analyzed and the data from the nine most consistent analytical results were used to calculate a concordia age of 1,796 $\pm 17 \mathrm{Ma}$ (Fig. 9). This result is interpreted as the crystallization age of the rock.

Sample TD-151 is from a Paranaíta Suite porphyry sienogranite. This sample provided medium sized zircon crystals, with prismatic bipyramidal habit, clear and with rare fractures. The analytical results showed low lead contents (expect in two samples with $f^{206}$ over $2.76 \%$ ) and $\mathrm{Th} / \mathrm{U}$ ratios over 0.23 . Among the data results from 16 analyzed crystals, 14 were selected to age calculation. The obtained data are reasonably

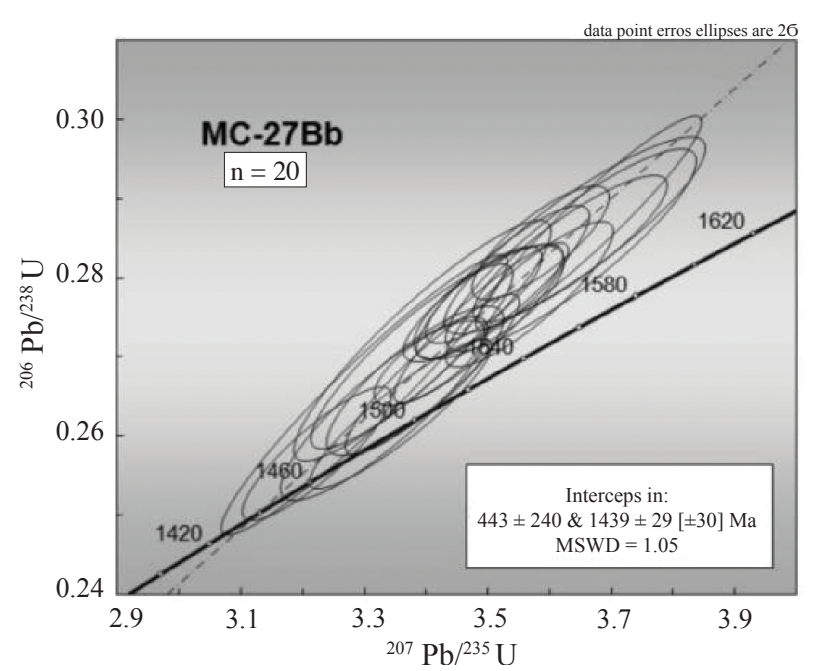

Figure 7-MC-027 Bb concordia diagram with all spots.

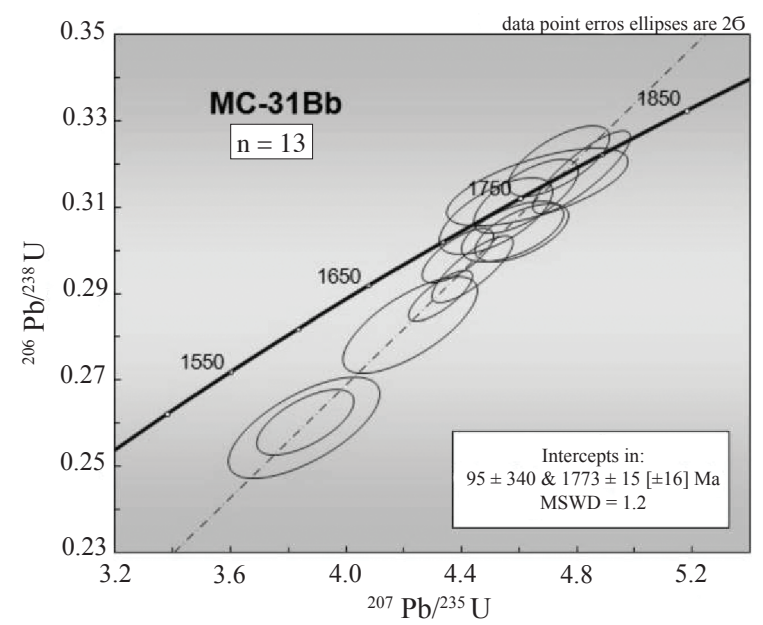

Figure 8-MC-031Bb concordia diagram with all spots. 
aligned, indicate a weak loss of lead and provided and upper intercept age of 1,797 $\pm 14 \mathrm{Ma}$ (Fig. 10).

\section{Samarium-Neodymium isotopes The Sm-}

$\mathrm{Nd}$ isotopic analyses were performed in ten samples. These samples are representative of each of the JMA lithostratigraphic units, except for the São Romão Granite. Also one sample from the Serra da Providência Suite was analyzed. With the results were calculated the model ages $\mathrm{T}_{\mathrm{DM}}$ and the $\varepsilon_{\mathrm{Nd}}$ values in $(0)$ and $(t)$, according to the crystallization age of each rock unit. Tab. 3 shows the results and other relevant information about the studied samples. The $\mathrm{Sm}$ and Nd contents vary between 4.28 and $20 \mathrm{ppm}$ and between 19 and 112 ppm, respectively. The model ages results are consistent Paleoproterozoic, between 1.85 and $2.25 \mathrm{Ga}$. The $\varepsilon_{\mathrm{Nd}(t)}$ values are slightly negative or positive, indicating the predominant influence of a primitive source magma.

DISCUSSION With the integration of the cartographic results from geological survey projects

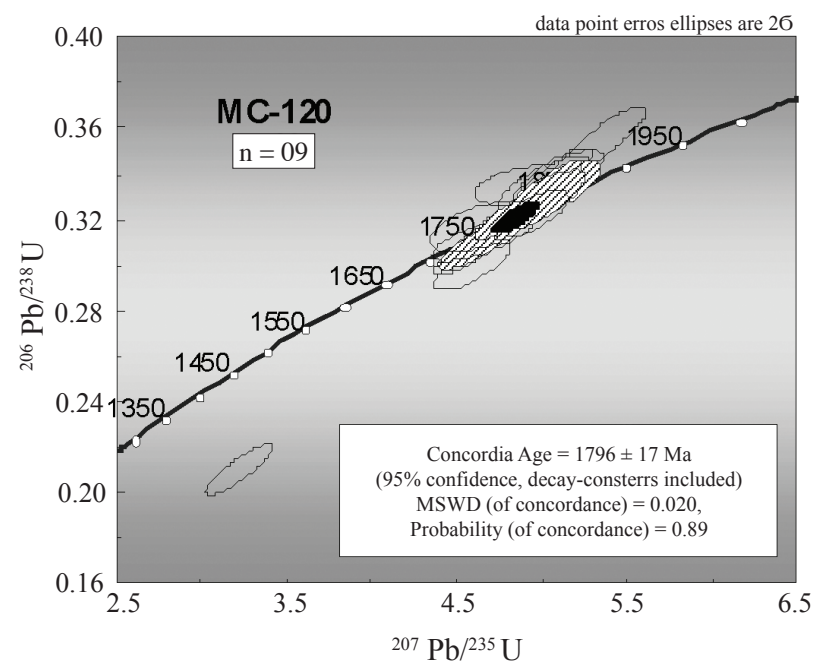

Figure 9-MC-120 concordia diagram. The empty circles represent discordant spots, not used in the age calculation.
(Souza et al. 2005, Oliveira \& Albuquerque 2007, Souza \& Abreu 2007, Martins \& Abdallah 2007, Knust 2010) combined with a broad dataset of geochronological results was possible to outline the JMA arrangement and define its position in the geological time scale. Fig. 2 summarizes those results. It is the geotectonical map from the NW of the Mato Grosso state originally published in the works of Ribeiro \& Duarte (2010) and Knust (2010). This figure illustrated the JMA, its stratigraphic column, the approximate limit between the magmatic arcs Tapajós and Juruena and the two geotectonical domains that configure the JMA. (1) The marginal ridge compound by the Colíder Group and the Paranaíta Suite and (2) The Bacaerí-Mogno and Juruena Complexes, representatives of oceanic and continental arc respectively. The geological maps and the spectrum of model and crystallization ages do not show significant differences between the domains to consider then as distinct magmatic arcs. Fig. 11 exemplifies the statement above through a graphic with model ages $\left(\mathrm{T}_{\mathrm{DM}}\right)$ and $\varepsilon_{\mathrm{Nd}(t)}$ values from JMA samples plotted. It can be

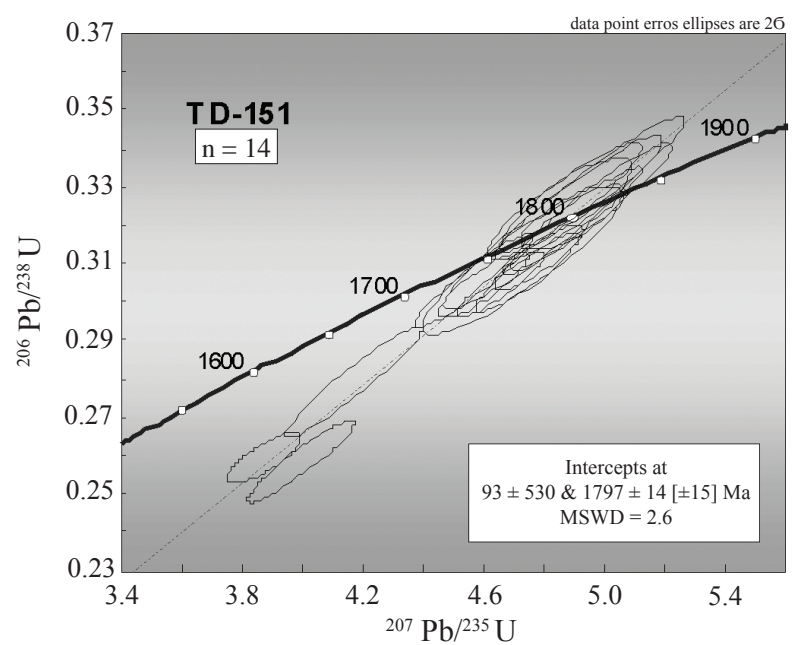

Figure 10-TD-151 concordia diagram with all spots.

Table 3 -Sm-Nd isotopic analysis results, $\varepsilon_{N d(0)}$ and $\varepsilon_{N d(t)}$ values, $T_{D M}$ model ages and crystallization age $(t)$ value

\begin{tabular}{lcccccccc}
\hline Sample & $\mathrm{Sm}(\mathrm{ppm})$ & $\mathrm{Nd}(\mathrm{ppm})$ & ${ }^{147} \mathrm{Sm} /{ }^{144} \mathrm{Nd}$ & ${ }^{143} \mathrm{Nd} /{ }^{144} \mathrm{Nd}( \pm 2 \mathrm{SE})$ & $\varepsilon_{\mathrm{Nd}(0)}$ & $\varepsilon_{\mathrm{Nd}(t)}$ & Time $(\mathrm{t})$ & $\mathrm{T}_{\mathrm{DM}}(\mathrm{Ga})$ \\
\hline MC-002 & 6.88 & 40.722 & 0.1021 & $0.511622 \pm 4$ & -19.83 & 1.92 & $1786 \pm 17$ & 1.93 \\
\hline TD-137 & 5902 & 33613 & 0.1061 & $0.511527 \pm 9$ & -21.67 & -0.91 & $1786 \pm 17$ & 2.14 \\
\hline MC-017 & 7.241 & 40.92 & 0.107 & $0.511679 \pm 5$ & -18.72 & 1.79 & $1785 \pm 6.3$ & 1.94 \\
\hline MC-058 & 7.075 & 38.587 & 0.1108 & $0.5117 \pm 11$ & -18.29 & 1.33 & $1767 \pm 08$ & 1.98 \\
\hline MC-120 & 5.713 & 35.428 & 0.0975 & $0.511513 \pm 6$ & -21.94 & 0.97 & $1796 \pm 17$ & 1.99 \\
\hline MC-140 & 6.849 & 38.387 & 0.1078 & $0.511641 \pm 9$ & -19.44 & 1.09 & $1796 \pm 17$ & 2.01 \\
\hline MC-031Bb & 4.277 & 19.894 & 0.13 & $0.511875 \pm 4$ & -14.89 & 0.35 & $1773 \pm 15$ & 2.11 \\
\hline MC-027Aa & 5.545 & 26.059 & 0.1153 & $0.511586 \pm 19$ & -20.52 & -1.9 & $1783 \pm 14$ & 2.25 \\
\hline TD-048B & 7.225 & 39.217 & 0.114 & $0.511714 \pm 3$ & -18.02 & 0.87 & $1783 \pm 14$ & 1.97 \\
\hline TD-034A & 20.662 & 112.558 & 0.111 & $0.511766 \pm 4$ & -17.01 & -0.09 & $1537 \pm 07$ & 1.88 \\
\hline
\end{tabular}


observed in the graphic that the $\mathrm{T}_{\mathrm{DM}}$ ages from both plutonovolcanic and complexes domain have virtually the same interval and also that the $\varepsilon_{\mathrm{Nd}(t)}$ values oscillates slightly positive to negative. These results denote equal magma generation periods, sources and crustal contamination processes that are typical of colisional orogens.

The JMA crystallization ages also support the theory of a single accretionary magmatic arc. The older rocks are at the NE of the area, in the plutonovolcanic domain, with ages between 1,808 and 1,766 Ma. This domain registers the entire range of ages of the arc formation, as expected for an active continental margin. To SW, toward the Juruena and Bacaerí-Mogno complexes, accounting for deeper rocks, the ages become slightly younger, between 1,787 and 1,764 Ma. Tab. 4 summarizes information about the samples with crystallization ages results used in the article.

About the crystallization ages results from the Roosevelt Group volcanic rocks, they show a younger interval of generation, between 1,772 and 1,740 Ma, when compared to the Colíder Group volcanic rocks. Previous works report two theories for this volcanic episode. Neder et al. (2002) describe it as the result from an anorogenic intracratonic extensional event. Rizzotto et al. (2004) views it as a retro-arc volcanism in relation to the JMA. Ribeiro \& Duarte (2010) did not identify structures or chemical signatures to interpret this volcanism as the result of an anorogenic extensional event, besides the results showed that these rocks have chemical characteristics of normal continental arc, with magmas generated in a subduction environment and with crustal contamination. The rocks which undoubtedly are correlated to a post-collisional period in relation to the JMA are from the Serra da Providência Suite. In the area these rocks are well preserved from the regional deformation and contain xenoliths from the enclosing units. The geochronological results presented in the Fig. 11 graphic and in the Tab. 4 show that both model $\mathrm{T}_{\mathrm{DM}}$ and crystallization ages are younger than what is expected for the JMA rocks. The chemical signatures show as well intra-plate, late-orogenic and mantle derived characteristics (Ribeiro \& Duarte 2010).

A final observation is that the three structural domains reflect the JMA geotectonic zonation. The brittle-ductile domain comprise the shallow crust plutonovolcanic belt, that is taken as the JMA paleo active continental margin; the ductile domain comprise the arc's righly deformed deep rocks from BacaeríMogno and Juruena complexes; and the brittle domain which comprise the post-collisional rocks from the Serra da Providência Suite.

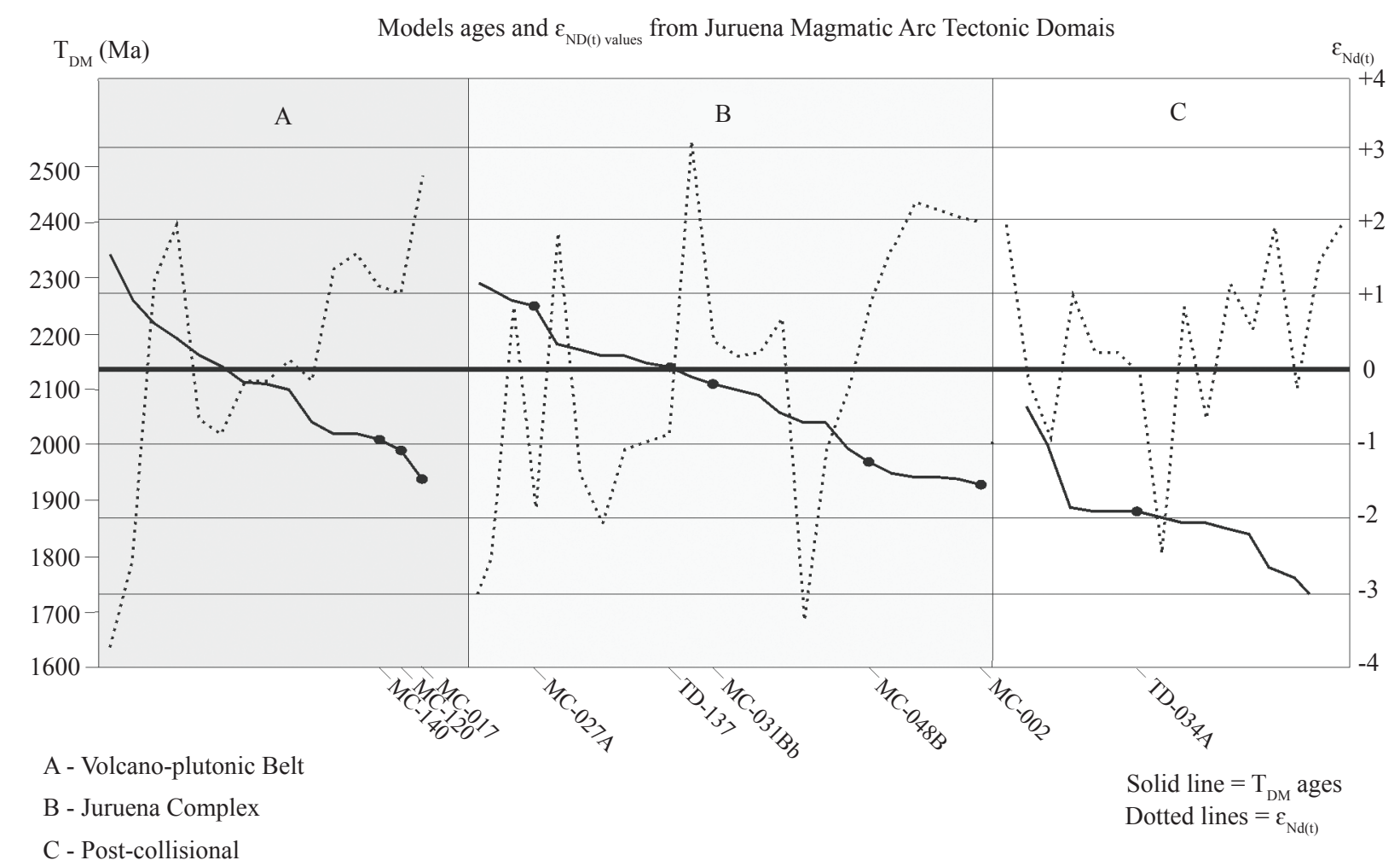

Figure 11 - Graphic with model ages (left y axis) and $\varepsilon_{\text {Nd(t) }}$ values (right $y$ axis) from rocks of the Juruena Magmatic Arc tectonic domains. 
Table 4-Available U-Pb crystallization ages for the Juruena Magmatic Arc available in the bibliography. The grey filled lines are samples results from the present work

\begin{tabular}{|c|c|c|c|c|c|c|}
\hline Sample & Longitude & Latitude & Lithology & Unit & Age (Ma) & Error \\
\hline aP29 & -59.12 & -9.15 & Monzogranite & $\mathrm{CG}$ & $1803^{(2)}$ & 3 \\
\hline${ }^{\mathrm{a} F i-05}$ & -59.12 & -9.00 & Máfic Tuff & $\mathrm{CG}$ & $1797^{(2)}$ & 5 \\
\hline${ }^{\circ} \mathrm{GM}-008$ & -53.97 & -10.52 & Rhyolite & $\mathrm{CG}$ & $1792^{(3)}$ & 8 \\
\hline${ }^{\mathrm{q}} \mathrm{F} 2001$ & -56.28 & -9.52 & Porfiy Rhyolite & $\mathrm{CG}$ & $1786^{(2)}$ & 17 \\
\hline${ }^{i}$ MA-004 & -57.05 & -9.35 & Porfiy Rhyolite & $\mathrm{CG}$ & $1785^{(3)}$ & 6.3 \\
\hline${ }^{\mathrm{h}} \mathrm{GM}-008$ & -55.04 & -10.88 & Porfiy Rhyolite & $\mathrm{CG}$ & $1781^{(2)}$ & 8 \\
\hline${ }^{\mathrm{h}} \mathrm{GM}-080$ & -55.04 & -10.88 & Monzogranite & $\mathrm{CG}$ & $1781^{(1)}$ & 8 \\
\hline${ }^{\mathrm{a} B}-04$ & -59.06 & -8.96 & Basalt & $\mathrm{CG}$ & $1776^{(2)}$ & 3 \\
\hline${ }^{\mathrm{a}} \mathrm{WB}-08$ & -59.07 & -8.97 & Ignimbrite & $\mathrm{CG}$ & $1774^{(2)}$ & 2 \\
\hline${ }^{\mathrm{a} B}-01$ & -59.02 & -8.96 & Rhyolite & $\mathrm{CG}$ & $1770^{(2)}$ & 8 \\
\hline${ }^{\mathrm{k}} \mathrm{RB}-012$ & -60.14 & -6.70 & Rhyolite & $\mathrm{CG}$ & $1766^{(3)}$ & 5.7 \\
\hline${ }^{\mathrm{i}} \mathrm{MA}-12 \mathrm{~A}$ & -55.94 & -9.82 & Bt Granite & PS & $1808^{(3)}$ & 14 \\
\hline${ }^{\mathrm{b}} \mathrm{TD}-151$ & -59.30 & -9.03 & Porfiry Sienogranite & PS & $1797^{(3)}$ & 14 \\
\hline${ }^{\mathrm{c}} \mathrm{CC}-21$ & -56.18 & -9.87 & Bt Porfiry Granite & PS & $1793^{(2)}$ & 6 \\
\hline${ }^{\mathrm{b}} \mathrm{MC}-120$ & -58.91 & -9.19 & Metamonzogranite & PS & $1769^{(3)}$ & 17 \\
\hline bPS-306 & -61.32 & -9.45 & Metagranodiorite & VPS & $1787^{(3)}$ & 14 \\
\hline hPS-042 & -57.79 & -9.80 & Tonalite & VPS & $1785^{(1)}$ & 8 \\
\hline${ }^{\mathrm{b}} \mathrm{MC}-27 \mathrm{Aa}$ & -59.13 & -9.42 & Metatonalite & VPS & $1783^{(3)}$ & 14 \\
\hline${ }^{\mathrm{h}} \mathrm{CC}-233$ & -56.73 & -9.97 & Enderbite & VPS & $1775^{(1)}$ & 10 \\
\hline${ }^{1} \mathrm{WA}-227 \mathrm{~A}$ & -58.46 & -10.87 & Tonalite & VPS & $1771^{(2)}$ & 14 \\
\hline${ }^{\mathrm{aP}} 21$ & -59.13 & -9.37 & Granodiorite & VPS & $1765^{(2)}$ & 4 \\
\hline${ }^{\mathrm{e}} \mathrm{CC}-138$ & -62.89 & -13.15 & Grt Bt Metagranite & SPG & $1786^{(1)}$ & 17 \\
\hline${ }^{\mathrm{h}} \mathrm{CC}-158$ & -56.65 & -9.92 & Metamonzogranite & SPG & $1784^{(1)}$ & 17 \\
\hline${ }^{\mathrm{a} A} 4$ & -59.37 & -9.27 & Hbl Metamonzogranite & SPG & $1775^{(2)}$ & 13 \\
\hline${ }^{\mathrm{a} A 3}$ & -59.35 & -9.29 & Bt Metamonzogranite & SPG & $1774^{(2)}$ & 4 \\
\hline${ }^{\mathrm{a}} \mathrm{P} 20$ & -59.13 & -9.38 & Gneiss & SPG & $1772^{(2)}$ & 66 \\
\hline${ }^{\mathrm{a} A} 8$ & -59.29 & -9.39 & Hbl Metamonzogranite & SPG & $1766^{(2)}$ & 5 \\
\hline${ }^{\mathrm{a} A} 7$ & -59.36 & -9.39 & Hbl Metamonzogranite & SPG & $1764^{(2)}$ & 32 \\
\hline${ }^{\mathrm{n}} \mathrm{SK}-055$ & -57.51 & -11.26 & Metamonzogranite & SPG & $1763^{(3)}$ & 37 \\
\hline aP25 & -59.12 & -9.35 & Ttn Bt Metamonzogranite & SPG & $1763^{(2)}$ & 6 \\
\hline${ }^{\mathrm{a} A 6}$ & -59.38 & -9.23 & Gneiss & SPG & $1759^{(2)}$ & 3 \\
\hline mParaibão & -59.54 & -10.08 & Porphyritic Granite & SPG & $1755^{(1)}$ & 5 \\
\hline bPS-019 & -60.39 & -9.36 & Metamonzogranite & SPG & $1730^{(3)}$ & 9 \\
\hline${ }^{1}$ WA-151 & -57.74 & -10.95 & Metamonzogranite & SRG & $1780^{(2)}$ & 13 \\
\hline bPS-064 & -60.06 & -9.87 & Metasienogranite & SRG & $1774^{(3)}$ & 28 \\
\hline hJD-017B & -56.40 & -10.21 & Bt Granite & SRG & $1770^{(1)}$ & 9 \\
\hline${ }^{\mathrm{b}} \mathrm{MC}-31 \mathrm{Bb}$ & -58.97 & -9.59 & Metagabbro & VMS & $1773^{(3)}$ & 15 \\
\hline bPS-029 & -60.07 & -9.55 & Metagabbro & VMS & $1764^{(3)}$ & 13 \\
\hline bPS-021 & -60.03 & -9.36 & Metadacite & RG & $1772^{(3)}$ & 12 \\
\hline${ }^{\mathrm{a} A} 1$ & -59.33 & -9.35 & Metarhyolite & RG & $1767^{(2)}$ & 2 \\
\hline${ }^{\mathrm{m}}$ Massaramduba & -59.54 & -10.08 & Metadacite & RG & $1762^{(1)}$ & 6 \\
\hline${ }^{\mathrm{a}} \mathrm{A} 2$ & -59.35 & -9.33 & Mylonitic Rhyodacite & RG & $1761^{(2)}$ & 5 \\
\hline 'MQ-96 & -60.80 & -11.48 & Dacite & RG & $1740^{(1)}$ & 8 \\
\hline${ }^{\mathrm{g} W B}-152$ & -62.22 & -9.47 & Paragneiss & $\mathrm{JC}$ & $1769^{(1)}$ & - \\
\hline${ }^{\mathrm{d}}$ GR-035 & -61.90 & -11.21 & Quartz Diorite & $\mathrm{JC}$ & $1758^{(1)}$ & 7 \\
\hline c5260-GR-35 & -61.89 & -11.20 & Gnaisse quartzo-diorítico & $\mathrm{JC}$ & $1757^{(1)}$ & 9 \\
\hline${ }^{\mathrm{d}} \mathrm{GR}-059$ & -62.90 & -9.80 & Tonalite & $\mathrm{JC}$ & $1753^{(1)}$ & 9 \\
\hline c2492-GR-59 & -62.90 & -9.80 & Tonalític Gneiss & $\mathrm{JC}$ & $1746^{(1)}$ & - \\
\hline c2492-JL-78 & -62.83 & -10.16 & Tonalítico Gneiss & $\mathrm{JC}$ & $1743^{(1)}$ & - \\
\hline${ }^{\mathrm{d} J L-078}$ & -62.83 & -10.16 & Tonalite & $\mathrm{JC}$ & $1738^{(1)}$ & 6 \\
\hline${ }^{g} \mathrm{WB}-70$ & -63.00 & -9.94 & Enderbític Granulite & $\mathrm{JC}$ & $1730^{(2)}$ & 22 \\
\hline
\end{tabular}


Table 4-Continuation

\begin{tabular}{|c|c|c|c|c|c|c|}
\hline Sample & Longitude & Latitude & Lithology & Unit & Age (Ma) & Error \\
\hline${ }^{j} \mathrm{PG}-J S-26$ & -64.92 & -9.61 & Tonalític Gneiss & $\mathrm{JC}$ & $1728^{(1)}$ & 15 \\
\hline fSP-GR-76 & -61.47 & -10.75 & Sienogranite & SPS & $1606^{(2)}$ & 24 \\
\hline${ }^{\mathrm{s}} \mathrm{GM}-033$ & -58.65 & -11.41 & Mylonitic Granite & SPS & $1580^{(2)}$ & 35 \\
\hline fSP-GR-21 & -61.61 & -10.81 & Monzogranite & SPS & $1573^{(2)}$ & 15 \\
\hline${ }^{\mathrm{f}} \mathrm{GR}-048$ & -64.99 & -9.04 & Granític Gneiss & SPS & $1570^{(1)}$ & 17 \\
\hline${ }^{g} \mathrm{MS}-6030$ & -62.12 & -9.65 & Granític Gneiss & SPS & $1570^{(2)}$ & 17 \\
\hline fSP-GR-39 & -61.63 & -11.05 & Monzogranite & SPS & $1566^{(2)}$ & 3 \\
\hline fSP-GR-48 & -61.42 & -10.75 & Monzogranite & SPS & $1566^{(2)}$ & 5 \\
\hline${ }^{1}$ WA-045 & -58.77 & -10.91 & Granodiorite & SPS & $1564^{(2)}$ & 12 \\
\hline gWB-46A/C & -63.04 & -9.97 & Monzogranític Gneiss & SPS & $1560^{(2)}$ & - \\
\hline jPG-JS-16 & -62.94 & -9.80 & Monzogranític Gneiss & SPS & $1555^{(1)}$ & 19 \\
\hline fSP-GR-53 & -61.59 & -10.78 & Sienogranite & SPS & $1554^{(2)}$ & 47 \\
\hline jPG-JS-19 & -61.00 & -11.51 & Sienogranitic Gneiss & SPS & $1545^{(1)}$ & 8 \\
\hline${ }^{\mathrm{g}} \mathrm{AR}-3 / 1$ & -63.46 & -8.81 & Monzogranite & SPS & $1544^{(2)}$ & 5 \\
\hline${ }^{\mathrm{k}} \mathrm{AR}-3-1$ & -63.46 & -8.81 & Bt Monzogranite & SPS & $1544^{(2)}$ & 5 \\
\hline 'MQ-33 & -59.56 & -10.11 & Ttn Bt Sienogranite & SPS & $1537^{(1)}$ & 7 \\
\hline jPG-JS-01 & -62.90 & -9.78 & Monzogranític Gneiss & SPS & $1535^{(1)}$ & 27 \\
\hline${ }^{g}$ WB-36 & -62.25 & -9.68 & Quartz-Sienite & SPS & $1532^{(2)}$ & - \\
\hline gWB-44A & -63.07 & -9.61 & Sienogranític Gneiss & SPS & $1526^{(2)}$ & 12 \\
\hline jPG-JS-32 & -61.41 & -11.46 & Monzogranític Gneiss & SPS & $1522^{(1)}$ & 10 \\
\hline${ }^{b}$ PS-170 & -60.51 & -9.01 & Hbl Bt Sienogranite & SPS & $1516^{(3)}$ & 11 \\
\hline${ }^{\mathrm{d}} \mathrm{GR}-333$ & -62.07 & -10.78 & Metagranite & SPS & $1515^{(1)}$ & 8 \\
\hline bPS-170 & -60.51 & -9.01 & Hbl Bt Sienogranito & SPS & $1505^{(3)}$ & 9.8 \\
\hline
\end{tabular}

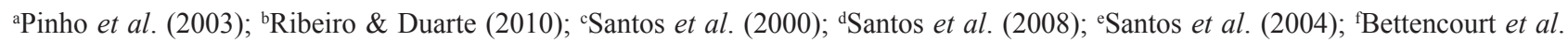

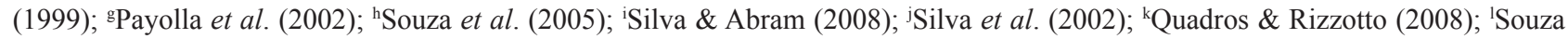

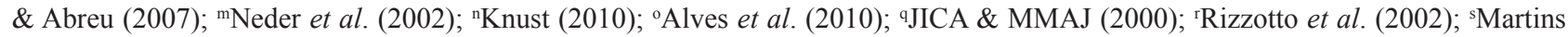
\& Abdallah (2007). ${ }^{(1)} \mathrm{U}-\mathrm{Pb}$ SHRIMP; ${ }^{(2)} \mathrm{U}-\mathrm{Pb}$ ID-TIMS; ${ }^{(3)} \mathrm{U}-\mathrm{Pb}$ ICP-MS-LA. CG: Colíder Group; PS: Paranaíta Suite; VPS: Vitória Plutonic Suite; SPG: São Pedro Granite; SRG: São Romão Granite; RG: Roosevelt Group; VMS: Vespor Mafic Suite; JC: Jamarí Complex; SPS: Serra da Providência Suite

\section{CONCLUSIONS The regional geological sur-} vey projects executed by the Brazilian Geological Survey (CPRM) in the Juruena Domain gather a major but crude dataset of geological data. Focused articles are important to publish and polish the results improving the area geological knowledge and economic potential. The conclusions from this article are:

A) The integration of the available 1:250,000 geological maps made possible prepare the geotectonic map from the NW of the Mato Grosso State and to adjust the limits between the Tapajós and Juruena Magmatic Arcs;

B) The area geologic map is more detailed and improved in relation to the previous $1: 1,000,000$ scale map. The main stratigraphic changes were in recognizing the Bacaerí-Mogno Complex, framing the deformed plutonic domain into the Juruena Complex and establish the unit Vespor Mafics to enclosure a series of mafic bodies and lenses previously unknown;
C) The geotectonic map, the litho-chemical interpretations and the geochronology data set allowed consolidate the Juruena Magmatic Arc as a single accretionary continental arc;

D) The range of $U-P b$ crystallization ages, $T_{D M}$ and $e_{\mathrm{Nd}(t)}$ values expected for the JMA are between 1,803 and $1,740 \mathrm{Ma}, 2,300$ and $1,950 \mathrm{Ma}$ and -3 to +3 , respectively.

E) The areas structural arrangement is also consistent with the model of a single continental arc. It was registered in the rocks a three stage progressive compressional deformation $\left(\mathrm{D}_{1}, \mathrm{D}_{2}\right.$ and $\left.\mathrm{D}_{3}\right)$ through the orogenesis, with the development of regional shear zones that affected both ductile and brittle domains;

F) Based on the results, the authors consider that it is adequate to use the term orogenesis to describe the JMA geological processes. 
G) It is necessary a large project to integrate the series of CPRM 1:250,000 recently published geological survey maps from the north of Mato Grosso State, southwest of Amazon Sate, south of Pará State and north/northeast of Rondônia State. This sort of work promotes the patterning of the litho-stratigraphic unit nomenclature and refines the Amazon Craton geotectonic evolutionary models thus supporting the discovery of new areas with economic potential.

ACKNOWLEDGEMENTS To the project funders: Brazilian Geological Survey (CPRM) and Mato Grosso State Secretary of Industry, Commerce, Mines and Energy (SICME-MT).

\section{References}

Alves C.L, Sabóia A.M., Martins E.G., Stropper J.L. 2010. Geologia e recursos minerais das Folhas Rio São José do Xingu e Rio Comandante Fontoura. Projeto Noroeste-Nordeste de Mato Grosso; Programa Geologia do Brasil (PGB). Goiânia: CPRM, 120 p., escala 1:250.000.

Bettencourt J.S., Tosdal R.M., Leite Jr W.B., Payolla B.L. 1999. Mesoproterozoic rapakivi granites of the Rondônia Tin Province, southwestern border of the Amazonian craton, Brazil - I. Reconnaissance U-Pb geochronology and regional implications. Precambrian Research, 95:41-67.

Bettencourt J.S., Leite Jr W., Payolla B., Ruiz A.S., Matos R.S., Tosdal R.M. 2010. The Rondonian-San Ignacio Province in the SW Amazonian Craton: an overview. Journal of South American Earth Sciences, 29:28-46.

Bühn B., Pimentel M.M., Matteini M., Dantas E.L. 2009. High spatial resolution analysis of $\mathrm{Pb}$ and $\mathrm{U}$ isotopes for geochronology by laser ablation multicollector inductively coupled plasma mass spectrometry (LAMC-ICP-MS). Anais da Academia Brasileira de Ciências, 81(1):1-16.

Cordani U.G. \& Teixeira W. 2007. Proterozoic accretionary belts in the Amazonian Craton. In: Hatcher Jr R.D., Carlson M.P., McBride J.H., Martinez-Catalan J.R. (eds.). 4-D Framework of Continental Crust, Memoir 200. Boulder, Geological Society of America, p. 297-320.

Cordani U.G., Teixeira W., D’Agrella-Filho M.S., Trindade R.I., 2009. The position of the Amazonian Craton in supercontinents. Gondwana Research, 15:396-407.

DePaolo D.J. 1981. A neodymium and strontium isotopic study of Mesozoic calc-alkaline granitic batholiths of Sierra Nevada and Peninsular Ranges, California. Journal of Geophysical Research, 86:10470-10488.

Gióia S.M.C.L \& Pimentel M.M. 2000. The Sm-Nd isotopic method in the geochronoogy laboratory of the University of Brasília. Anais da Academia Brasileira de Ciências, 72(2):219-245.

JAPAN INTERNATIONAL COOPERATION AGENCY (JICA), METAL MINING AGENCY OF JAPAN (MMAJ). 2001. Report on the mineral exploration in the Alta Floresta area, Federative Republic of Brazil: phase III. Tokyo: JICA; MMAJ.

Klein E.L. 2001. Geologia e Recursos Minerais da Província Mineral do Tapajós. Programa Levantamentos Geológicos Básicos do Brasil (PLGB),
Projeto Especial Província Mineral do Tapajós (PROMIM TAPAJÓS). Brasília, CPRM.

Knust S.S.A. 2010. Geologia e recursos minerais da Folha Porto dos Gaúchos. Projeto Noroeste-Nordeste de Mato Grosso; Programa Geologia do Brasil (PGB). Goiânia: CPRM, 141 p., escala 1:250.000.

Leal J.W.L. 1978. Projeto RADAMBRASIL. Folha SC. 20. Porto Velho: Geologia, Geomorfologia, Pedologia, Vegetação e Uso Potencial da Terra. Rio de Janeiro: DNPM, 17-184.

Ludwig K.R. 2003. Isoplot 3.00 - a geochronological toolkit for Microsoft Excel. Berkeley Geochronology Center, Special Publication No 4.

Martins E.G. \& Abdallah S. 2007. Geologia e recursos minerais da folha Juína SC.21-Y-C. Projeto Noroeste de Mato Grosso, Programa Geologia do Brasil (PGB). Goiânia: CPRM. 98 p. il., escala 1:250.000.

Marzoli A., Renne P.R., Piccirillo E.M., Ernesto M., Bellieni G., Min A.D. 1999. Extensive 200-MillionYear-Old Continental Flood Basalts of the Central Atlantic Magmatic Province. Science, 284:616-618.

Neder R.D., Leite J.A.D, Figueiredo B.R., McNaughton N.J. 2002. 1.76 Ga volcano-plutonism in the southwestern Amazonian craton, Aripuanã-MT, Brazil: tectono-stratigraphic implications from SHRIMP U-Pb zircon data and rock geochemistry. Precambrian Research, 119:171-187.

Oliveira C. C. \& Albuquerque M.C. 2007. Geologia e recursos minerais da folha Aripuanã SC. 21-Y-A. Projeto Noroeste de Mato Grosso, Programa Geologia do Brasil (PGB). Goiânia: CPRM. 92 p. il., escala $1: 250.000$.

Payolla B.L., Bettencourt J.S., Kozuch M., Jeite Jr. W.B., Fetter A.H., VanSchmus W.R. 2002. Geological evolution of the basement rocks in the east-central part of the Rondônia Tin Province, SW Amazonian craton, Brazil: U-Pb and $\mathrm{Sm}-\mathrm{Nd}$ isotopic constrainsts. Precambriam Research, 119:141-169.

Pinho M.S.B., Chemale Jr. F., Schmus R.V., Pinho F.E.C. 2003. U-Pb and $\mathrm{Sm}-\mathrm{Nd}$ evidence for 1.76-1.77 Ga magmatism in the Moriru region, Mato Grosso, Brazil: implications for province boundaries in the SW Amazon Craton. Precambrian Research, 126:1-25.

Quadros M.L.E.S. \& Rizzotto G.J. 2008. Mapa geológico e de recursos minerais do Estado de Rondônia estruturado em Sistema de Informações Geográficas (SIG). In: 
CONGRESSO BRASILEIRO DE GEOLOGIA, 44., 26-31 out. 2008, Curitiba, PR. Anais... Curitiba, PR: SBG, 2008.

Ribeiro P.S.E. \& Duarte T.B. 2010. Geologia e Recursos Minerais das Folhas Rio Guariba e Rio Aripuanã. Projeto Noroeste-Nordeste de Mato Grosso; Programa Geologia do Brasil (PGB). Goiânia: CPRM, 248 p., escala 1:250.000.

Rizzotto G.J., Quadros M.L.E.S, Silva L.C, Armstrong R., Almeida M.E. 2002. O Granito Aripuanã: Datação U-Pb (SHRIMP) e Implicações Metalogenéticas. In: CONGRESSO BRASILEIRO DE GEOLOGIA, 41., João Pessoa. Anais... João Pessoa: SGB, 2002. p. 469-469.

Rizzotto G.J., Quadros M.L.E.S., Bahia R.B.C, Ferreira R.B.C, Lopes R.C, Cordeiro A.V. 2004. Folha SC.21Juruena. In: Schobbenhaus C., Gonçalves J.H., Santos J.O.S., Abram M.B., Leão Neto R., Matos G.M.M., Vidotti R.M., Ramos M.A.B., Jesus J.D.A (eds). Carta Geológica do Brasil ao Milionéssimo. Sistema de informações Geográficas. Programa Geologia do Brasil. 46 folhas. Brasília: Companhia de Pesquisa de Recursos Minerais, escala 1:1.000.000. 41 CD-ROM.

Santos J.O.S., Rizzotto G.J., Easton M. R., Potter P.E., Hartmann L.A., McNaughton N.J. 2002. The Sunsás orogen in western amazon craton, South América and correlation with the Grenville Orogen of Laurentia, base on U-Pb Isotopic Study of Detritical and Igneous Zircon. Geological Society of America - Denver Annual Meeting. Precambrian Geology, 122:27-30.

Santos J.O.S, Rizzoto G.J., Potter P.E., McNaughton N.J., Matos R.S., Hartmann L.A., Chemale Jr F., Quadros M.E.S. 2008. Age and autochthonous evolution of the Sunsás Orogen in West Amazon Craton based on mapping and $\mathrm{U}-\mathrm{Pb}$ geochronology. Precambrian Research, 165:120-152.

Santos J.O.S., Hartmann L.A., Gaudette H.E., Groves D.I., McNaughton N.J., Fletcher I.R. 2000. A new undestanding of the provinces of the Amazon craton based on integration of Field mapping and U-Pb and SmNd geochronology. Gondwana Research, 4:453-488.

Santos J.O.S., Van Breemen O.B., Groves D.I., Hartmann L.A., Almeida M.E., McNaughton N.J., Fletcher I.R. 2004. Timing and evolution of multiple Paleoproterozoic magmatic arcs in the Tapajós Domain, Amazon Craton: constrains from SHRIMP and TIMS zircon, baddeleyite and titanite U-Pb geochronology. Precambrian Research, 131:73-109.
Sato K. \& Tassinari C.C.G. 1997. Principais eventos de acresção continental no cráton amazônico baseados em idade modelo Sm-Nd, calculada em evoluções de estágio único e estágio duplo. In: Costa M.L., Angélica R.S. Contribuições à Geologia da Amazônia. Belém: FINEP; SBG, p. 91:129.

Scandolora J. E. 2006. Geologia e evolução do terreno Jamari, embasamento da faixa Sunsas-Aguapeí, centroleste de Rondônia, sudoeste do craton Amazônico. Tese (Doutorado em Geologia Regional) - Instituto de Geociências, Universidade de Brasília, Brasília. 383p.

Silva L.C, Armstrong R., Pimentel M.M., Scandolara J.E., Ramgrab G., Wildner W., Angelim L.A.A., Vasconcelos A.M., Rizzotto G.J., Quadros M.L.E.S., Sander A., Rosa A.L.Z. 2002. Reavaliação da evolução geológica em terrenos pré-cambrianos brasileiros com base em novos dados U-Pb SHRIMP, parte III: Províncias Borborema, Mantiqueira Meridional e Rio Negro-Juruena. Revista Brasileira de Geociências, 32(4):529-544.

Silva M.G. \& Abram M.B. 2008. Projeto Metalogenia da Província Aurífera Juruena-Teles Pires. Informe de Recursos Minerais. Série Ouro, 16. Programa Geologia do Brasil - PGB. CPRM Goiânia.

Souza J.O. \& Abreu F.W. 2007. Geologia e recursos minerais da folha Tapaiúna SC.21-Y-B. Projeto Noroeste de Mato Grosso, Programa Geologia do Brasil (PGB). Goiânia: CPRM. 88 p. il, escala 1:250.000.

Souza J.O., Frasca A.A.S., Oliveira C.C. 2005. Geologia e recursos minerais da província mineral de Alta Floresta: relatório integrado. Programa Levantamentos Geológicos Básicos do Brasil (PLGB), Projeto Província Mineral de Alta Floresta (Promin Alta Floresta). CPRM Goiânia, escala 1:500.000.

Tassinari C.C.G. 1996. O mapa geocronológico do Cráton Amazônico no Brasil: revisão dos dados isotópicos. Tese (Livre-docência) - Instituto de Geociências, Universidade de São Paulo, São Paulo.

Tassinari C.C.G., Macambira M.J.B. 1999. Geochronological provinces of the Amazon craton. Episodes, 22:174-182.

Manuscrito ID 22501

Recebido em: 08/08/2011 Aprovado em: 11/10/2012 